\title{
A seismic geotraverse across the Iberian Variscides: Orogenic shortening, collisional magmatism, and orocline development
}

\author{
J. F. Simancas, ${ }^{1}$ P. Ayarza, ${ }^{2}$ A. Azor, ${ }^{1}$ R. Carbonell, ${ }^{3}$ D. Martínez Poyatos, ${ }^{1}$ \\ A. Pérez-Estaún, ${ }^{3}$ and F. González Lodeiro ${ }^{1}$ \\ Received 8 November 2012; revised 27 February 2013; accepted 15 March 2013; published 30 May 2013.
}

[1] A crustal geotraverse through the Iberian Variscides is presented by integrating the available geological and seismic profiling data. Different modes of orogenic shortening are identified, with varying degrees of coupling between upper and lower crust. In northern and southern regions of the geotraverse, a decoupling in the middle crust permits the lower crust to subduct/underthrust, thus compensating for strong upper crustal shortening. This behavior does not result in great crustal thickening, except in sectors of crustal underthrusting. In southern Central Iberia, moderate upper crustal shortening is due to a mechanically strong lower crust impeded to subduct/underthrust. In this region, shortening is partitioned between upper and lower crust, deformation being distributed in the upper crust while localized at major fault zones in the lower crust. Finally, the central region of the geotraverse (northern Central Iberia) shows a coupled crustal deformation, having given way to the largest orogenic thickening in the Iberian Variscides. The thermal maturity of this much thickened crust originated voluminous crustal melting, and concomitant normal-fault detachments developed, while shortening dominated in other regions. Theoretical models suggest that compressive stresses may prevail in the lower crust beneath the extending upper crust, thus explaining the efficient syncollisional exhumation in this part of the orogen. A particular feature of the Iberian Variscan geotraverse is the great importance of out-of-section mass movements, mainly left-lateral shear zones concentrated in two suture boundaries, which displaced to the NW (present coordinates) central and northern Iberia with respect to southern Iberia.

Citation: Simancas, J. F., P. Ayarza, A. Azor, R. Carbonell, D. Martínez Poyatos, A. Pérez-Estaún, and F. González Lodeiro (2013), A seismic geotraverse across the Iberian Variscides: Orogenic shortening, collisional magmatism, and orocline development, Tectonics, 32, 417-432, doi:10.1002/tect.20035.

\section{Introduction}

[2] The benefits of normal incidence deep seismic reflection profiles have been long recognized by Earth's scientists. Deep seismic research programs such as Consortium for Continental Reflection Profiling [Cook et al., 1981; Brown et al., 1983], LITHOPROBE [Clowes et al., 1996, Cook et al., 1999; Hammer et al., 2011], DEKORP [DEKORP Research Group, 1985, 1990, 1991] and Urals Seismic Experiment and Integrates Studies/ESRU [Echtler et al., 1996; Juhlin et al., 1998; Tryggvason et al., 2001] have provided large amounts of data to understand the internal architecture and tectonic evolution of the Earth's crust. These seismic geotraverses have generated the highest resolution images of key geological structures within the continental landmasses and surrounding

\footnotetext{
${ }^{1}$ Geodynamics Department, Granada University, Granada, Spain.

${ }^{2}$ Geology Department, Salamanca University, Salamanca, Spain.

${ }^{3}$ Earth Science Institute "Jaume Almera", CSIC, Barcelona, Spain.

Corresponding author: J. F. Simancas, Geodynamics Department, Granada University, Granada, Spain. (simancas@ugr.es)

(C2013. American Geophysical Union. All Rights Reserved. 0278-7407/13/10.1002/tect.20035
}

offshore margins, providing a link between surface geology and large-scale processes sourced deep in the Earth.

[3] The Iberian Variscides have been widely studied by deep seismic profiling over the last 20 years. A number of government-funded research programs, namely the ESCI-N project (ESCI-N1, Pérez Estaún et al. [1994]; ESCI-N3.1, 3.2, and 3.3, Martínez Catalán et al. [1995], Alvarez Marrón et al. [1996], Ayarza et al. [1998, 2004]), the IBERSEIS project [Simancas et al., 2003; Carbonell et al., 2004; Flecha et al., 2009; Palomeras et al., 2009], and the ALCUDIA experiment [Martínez Poyatos et al., 2012], have imaged the continental crust and upper mantle beneath the Iberian Peninsula, with extensive and high-quality lithospheric seismic transects of the southernmost part of the European Variscides. The data provided by these experiments have been, up to now, interpreted separately, on the basis of regional geology. This paper aims to integrate all the deep vertical incidence seismic profiles recorded in the Iberian Variscides and interpret them globally, addressing the following key issues: (i) accommodation of orogenic shortening at crustal scale, (ii) relationships between convergence, crustal thickening and collisional granitic magmatism, and (iii) development of the Iberian Variscan orocline. 


\section{Geological Setting}

[4] The Iberian Massif provides a nearly complete section of the Late Palaeozoic Variscan-Alleghanian orogen (Figure 1a), though the undeformed forelands do not crop out and important lateral displacements took place across the section. Besides this Palaeozoic orogen, the Iberian Massif exhibits a number of late Neoproterozoic outcrops that record earlier events of Late Precambrian (Cadomian) age. A geologically based zoning of the Iberian Massif is now firmly established, comprising six zones described below (Figure 1b).

[5] The Cantabrian zone (Figures $1 \mathrm{~b}$ and $2 \mathrm{~b}$, ESCI-N1 deep seismic profile) is characterized by the following: (i) pre-orogenic sediments up to the Lower Carboniferous and Upper Carboniferous syn-orogenic sediments, (ii) thinskinned, east-vergent orogenic deformation, and (iii) weak strain and no metamorphism. On these grounds, the Cantabrian zone is interpreted to have had an external position in the orogen, with the foreland located somewhere to the east in present-day coordinates [Pérez Estaún et al., 1988]. The transition to the hinterland of the orogen is represented by the West Asturian-Leonese zone, which displays (Figures $1 \mathrm{~b}$ and 2c, ESCI-N3.3 profile; Pérez Estaún et al. [1991]; Marcos [2004]) the following: (i) a much thicker Lower Palaeozoic sequence than the Cantabrian zone, (ii) east-vergent overturned to recumbent folds and thrusts, (iii) a detachment level deeper than that of the Cantabrian zone, and (iv) pervasive strain and metamorphism. Moreover, granites appear at the boundary with the next zone.

[6] The Central Iberian zone is the largest one and shows noticeable differences from north to south (Figure 1b; Martinez Catalán et al. [2004]). The northern half exhibits the following: (i) intense deformation and high-grade metamorphism affecting the middle-lower crust [Macaya et al., 1991; Barbero and Villaseca, 2000], (ii) ductile extensional detachments thinning a previously thickened crust [Escuder Viruete et al., 1994, 1998; Diez Balda et al., 1995; Valle Aguado et al., 2005; Rubio Pascual et al., 2013], and (iii) an enormous volume of Late Carboniferous granites [e.g., Bea, 2004]. By contrast, the southern half of the Central Iberian zone (Figure 2d, ALCUDIA seismic profile) displays weaker deformation, low-grade metamorphism, and moderate granitic plutonism.

[7] The Ossa-Morena zone (Figure 1b) is separated from the Central Iberian zone by a major crustal-scale shear zone [Burg et al., 1981; Azor et al., 1994], which has been seismically imaged as dipping to the northeast (Figure 2e, IBERSEIS profile). This shear zone contains lenses of retro-eclogitic metabasites wrapped in migmatitic gneisses, orthogneisses, and mylonitic schists. It exposes rocks of high to low metamorphic conditions, with widespread leftlateral kinematics. Some lenses of metabasites have been dated as Late Neoproterozoic, but most of them and all of the orthogneisses have Late Cambrian to Early Ordovician ages [Schäfer, 1991; Oschner, 1993; Ordóñez Casado, 1998]. To the south of this major shear zone, which may represent a suture contact [Simancas et al., 2001; Gómez Pugnaire et al., 2003], the Ossa-Morena zone displays distinctive features: (i) a well-developed pre-Variscan (Lower Palaeozoic) magmatic rift fragmentation of the Gondwana border, (ii) a Devonian deformation characterized by recumbent, southwest-vergent folds and thrusts
(Figure 2e, IBERSEIS profile), (iii) a transient Early Carboniferous stage of extension, magmatism (largely mafic), and basin development, after which orogenic shortening resumed, and (iv) a very reflective seismic body in the middle crust, interpreted as sill-like mafic rocks interlayered with metasediments, tentatively related to the Early Carboniferous magmatism outcropping at surface (Simancas et al. [2003]; Carbonell et al. [2004]; Figure 2e, IBERSEIS profile).

[8] The boundary between the Ossa-Morena and the South Portuguese zones (Figure 1b) is interpreted as the suture of the Rheic ocean [e.g., Crespo-Blanc and Orozco, 1988; Fonseca and Ribeiro, 1993; Simancas et al., 2003]. This interpretation has been challenged by recent Early Carboniferous ages of rocks supposedly representing a Rheic ophiolite [Azor et al., 2008, 2009], but it is still supported by the presence of an allochthonous complex with eclogites, high-pressure schists, and mid-ocean ridge basalt (MORB)-type metabasites [Fonseca et al., 1999; Pedro et al., 2010; Ponce et al., 2012]. South of the suture, the South Portuguese zone displays the following features: (i) outcrops exclusively of Devonian and Carboniferous rocks, (ii) an Early Mississippian magmatic rifting stage (and associated giant sulfide deposits), and (iii) a Mississippian-Pennsylvanian foldand-thrust, thin-skinned tectonics of southward vergence (Figure 2e, IBERSEIS profile). The South Portuguese zone is usually correlated with the Rheno-Hercynian zone of central Europe, thus assuming an external position for it, despite its very particular magmatic evolution.

[9] Finally, the Galicia Tras-Os-Montes zone is allochthonous over the Central Iberian zone (Figure 1b) and represents a thick tectonic pile of continental and oceanic units. The unrooted suture contained in this complex (its ophiolitic units) is generally interpreted as the Rheic suture of the Variscan orogen [Martínez Catalán et al., 1996; Arenas et al., 2004].

[10] To sum up, the Iberian geotraverse of the Variscides shows the following: (i) two external zones, the Cantabrian and the South Portuguese zones, with the zones in-between corresponding to internal parts of the orogen (Figure 1b), (ii) the Rheic ocean suture located at the boundary between the Ossa-Morena and the South Portuguese zones and within the allochthonous Galicia Tras-Os-Montes zone, (iii) another major tectonic contact at the boundary between the OssaMorena and the Central Iberian zone, (iv) deformation that started in Early Devonian times at suture zones and reached the external regions in Late Carboniferous times, (v) a huge volume of collisional Late Carboniferous granites in the northern half of the Central Iberian zone, and (vi) intracollisional magmatic rifting of Early Carboniferous age that affected uniquely SW Iberia. Correlations of the Iberian Variscan sutures and zones with those of Central Europe and Morocco have been presented in a number of papers [e.g., Matte, 1986, 2001; Franke, 2000; Simancas et al., 2005; Martínez Catalán, 2011]. There is no full agreement in these correlations, but a discussion of this subject is beyond the scope of this paper.

[11] The Iberian Variscides have been long recognized as part of the Ibero-Armorican arc [Matte and Ribeiro, 1975], but a wider S-shaped orocline structure has been highlighted recently [Aerden, 2004; Martínez Catalán, 2011, 2012; Shaw et al., 2012]. This orocline structure will be discussed in a later section. 


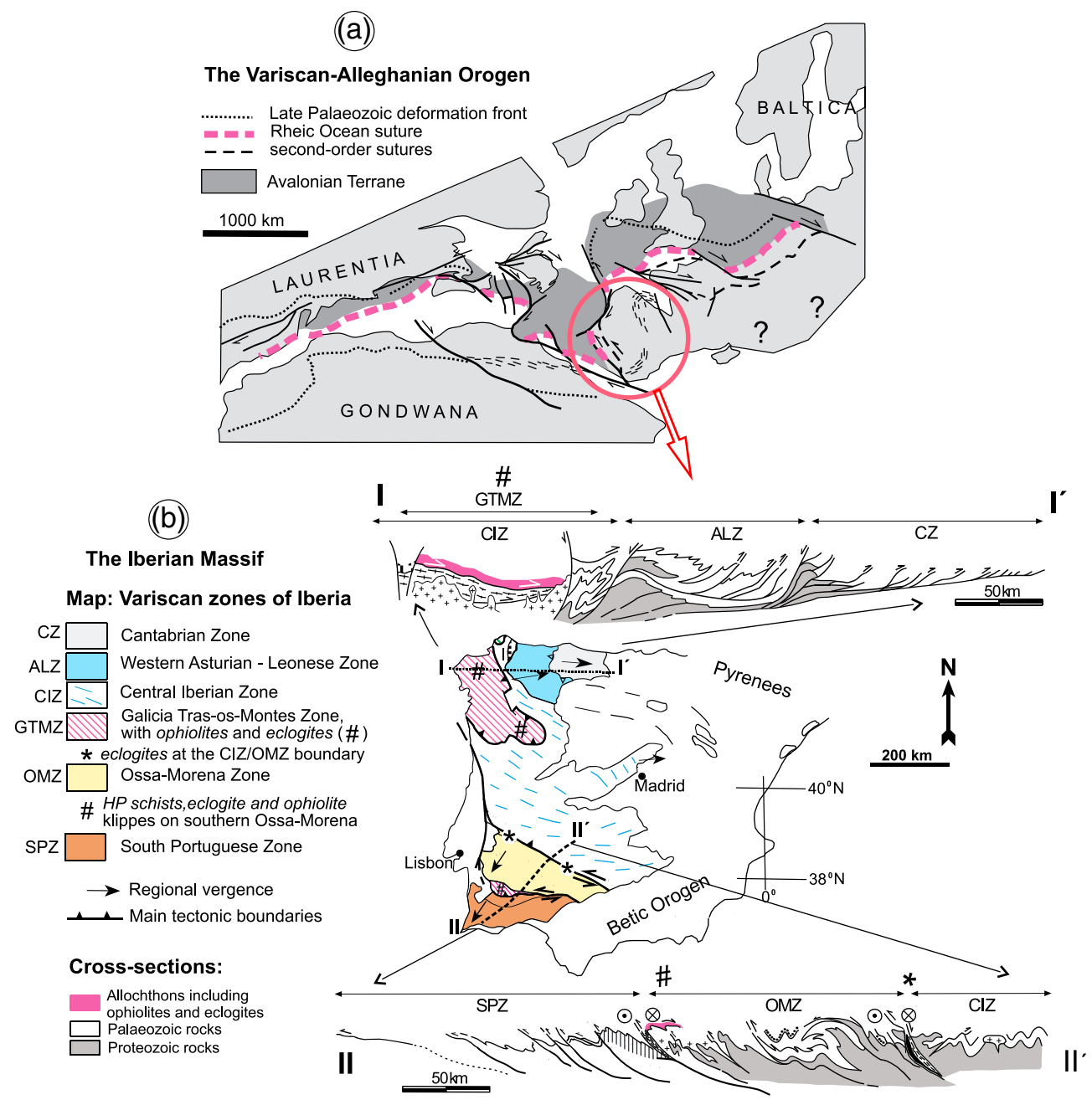

Figure 1. (a) Iberia (circled area) in the context of the Variscan-Alleghanian orogen. (b) Tectonostratigraphic zones and general geological cross-sections of the Iberian Variscides.

\section{Normal Incidence Deep Seismic Reflection Data}

[12] The Spanish seismic reflection projects ESCI-N, IBERSEIS and ALCUDIA have acquired a series of transects along Northern and Southern Iberia (Figure 2a). The seismic data have been obtained within a time span of almost 20 years, thus featuring different acquisition instrumentation, parameters, and schemes. The ESCI-N1 deep seismic reflection transect was carried out in 1991 using a commercial crew and a 240-channel SERCERL SN 348 seismic data acquisition system. The source consisted in $20 \mathrm{~kg}$ of dynamite in a single $24 \mathrm{~m}$-deep borehole, with the receiver station spaced $60 \mathrm{~m}$. The data were recorded using a split spread setup, and the final average coverage was of $3000 \%$. The record length was $25 \mathrm{~s}$. Further information on this acquisition is given by Pérez Estaún et al. [1994]. The ESCI-N3.2 and 3.3 [Martínez Catalán et al., 1995; Ayarza et al., 1998, 2004] are offshore seismic lines. They were recorded in 1993 using the state-of-the-art M/V Seisquest, from Geko-Prakla-Schlumberger. An array of airguns with a total volume of $90 \mathrm{~L}$ was used to generate $75 \mathrm{~m}$ spaced shots that were recorded by a streamer with hydrophones located $25 \mathrm{~m}$ apart. Record length was $20 \mathrm{~s}$ and the maximum fold 3000\% [Ayarza et al., 1998]. In contrast, the IBERSEIS and ALCUDIA experiments were acquired in 2001 and 2007, respectively, by student crews but with equipment and collaboration of CGG-Veritas. The Vibroseis source spacing was $70 \mathrm{~m}$ with the receivers spaced $35 \mathrm{~m}$. Six sweeps were vibrated at each source point using four Vibrator trucks. The sweep length was $20 \mathrm{~s}$ with $40 \mathrm{~s}$ of listening time, resulting in a $20 \mathrm{~s}$ trace length. A 400-channel SERCEL 388 system was used for the acquisition in an asymmetric split spread setup. This acquisition parameter setup resulted in a minimum fold of 6000\% [Simancas et al., 2003; Carbonell et al., 2004; Martínez Poyatos et al., 2012].

[13] There are noticeable differences between the quality of the seismic images provided by ESCI-N project and the more recent IBERSEIS and ALCUDIA experiments, which are mostly due to the different acquisition parameters and instruments used. The signal/noise ratio and sharpness of the images have increased with the quality of the equipment and the careful design of the acquisition parameters, most modern transects probably featuring the highest lateral resolution. 

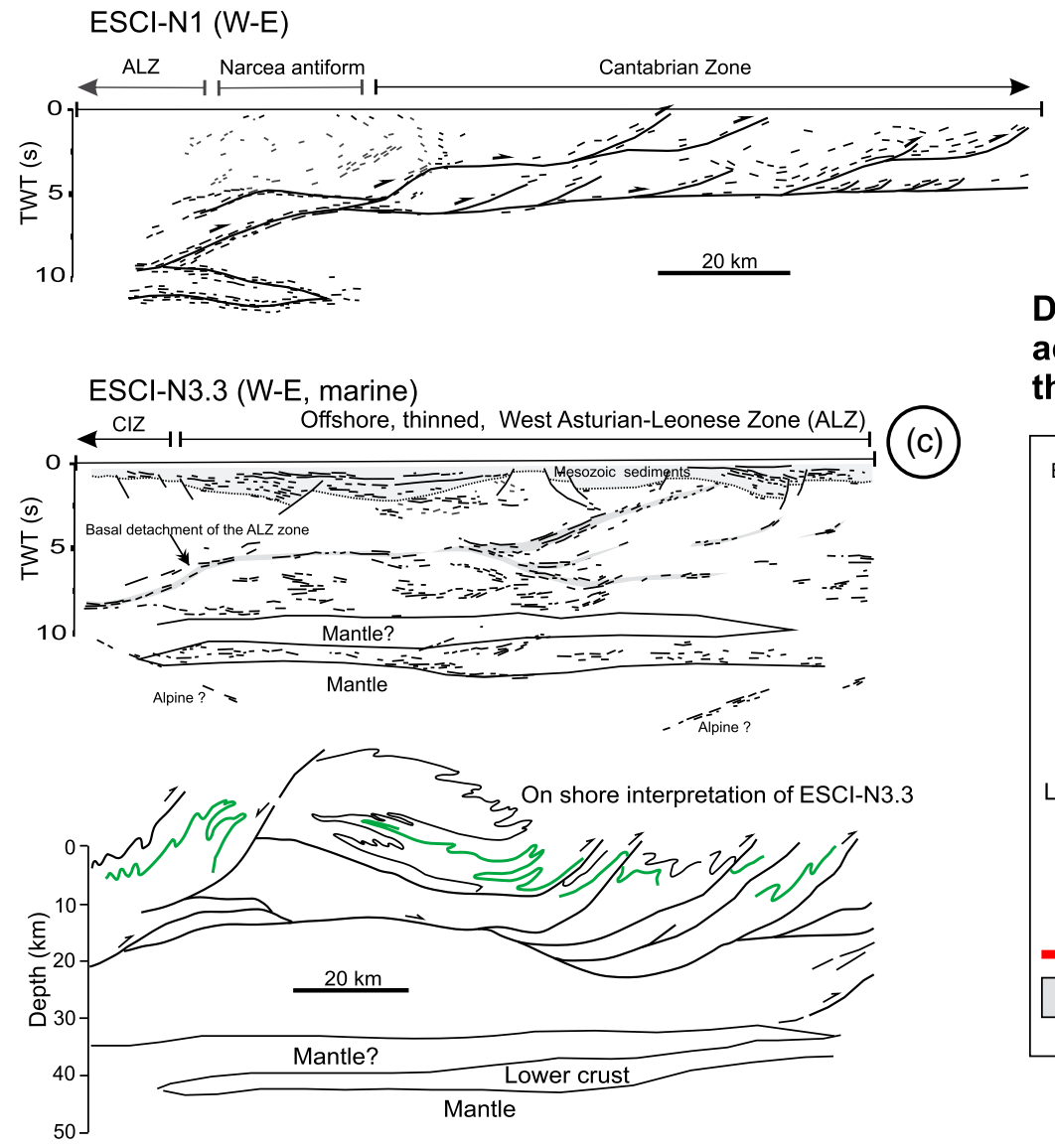

(c)

\section{Deep Seismic Reflection Profiles across the Variscan crust of the Iberian Peninsula}
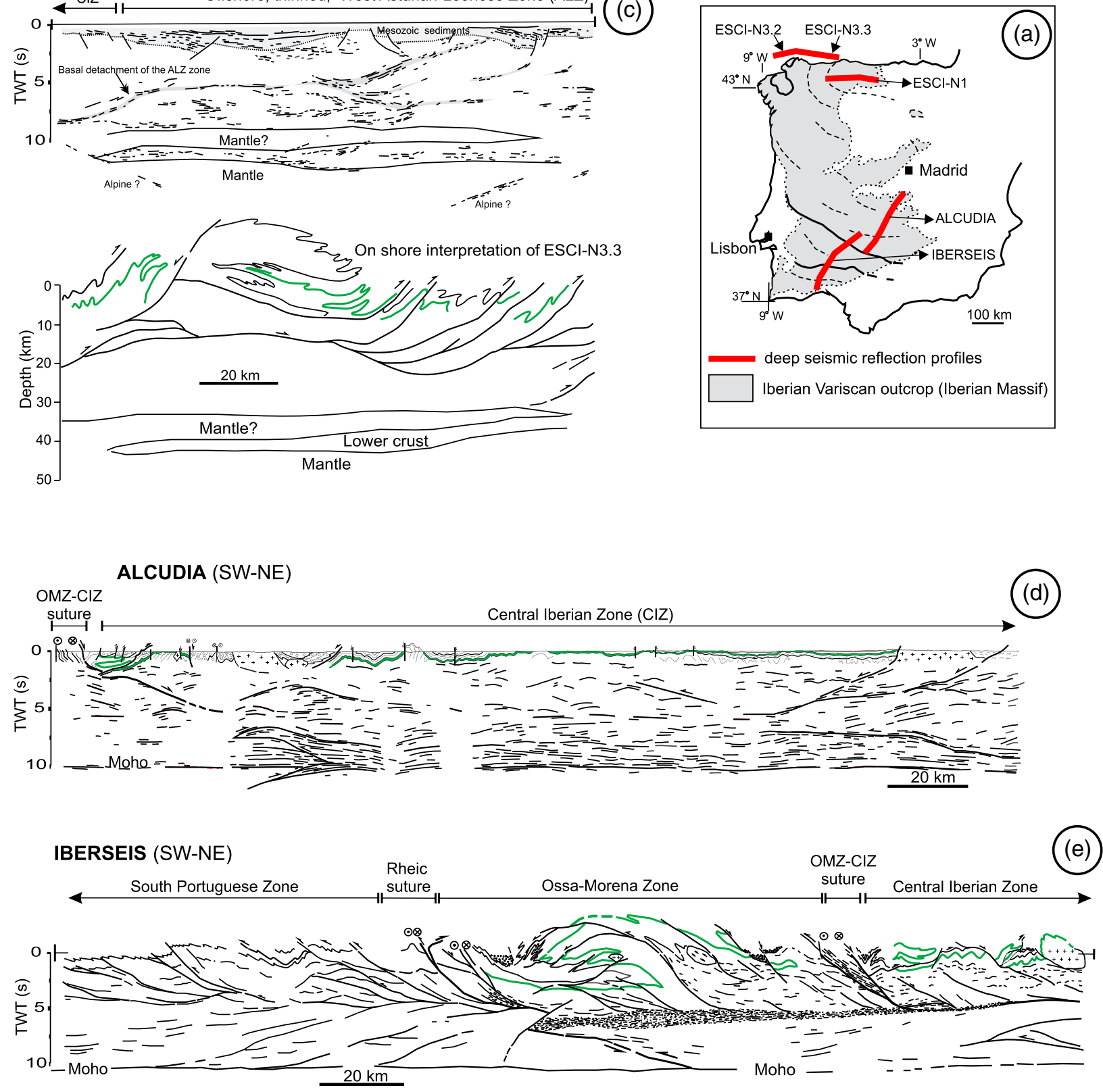

Figure 2. (a) Location of the Deep Seismic Reflection Profiles (thick red lines) sampling the Variscan crust of Iberia. (b) Line drawing and interpretation of the ESCI-N1 seismic line [Pérez Estaún et al., 1994]. (c, upper figure) Line drawing and interpretation of the marine ESCI-N3.3 seismic line. Note Mesozoic basins, i.e., thinning of the Variscan crust [Martínez Catalán et al., 1995]. (c, lower figure) Onshore interpretation of the Variscan reflectors in ESCI-N3.3, based on outcropping geology [Ayarza et al., 1998]. (d) Line drawing and interpretation of the ALCUDIA seismic line (Martinez Poyatos et al., 2012). (e) Line drawing and interpretation of the IBERSEIS seismic line [Simancas et al., 2003]. Green line in Figures 2c, 2d, and 2e indicates the Lower Ordovician strata as a reference level in the geological cross-sections. 


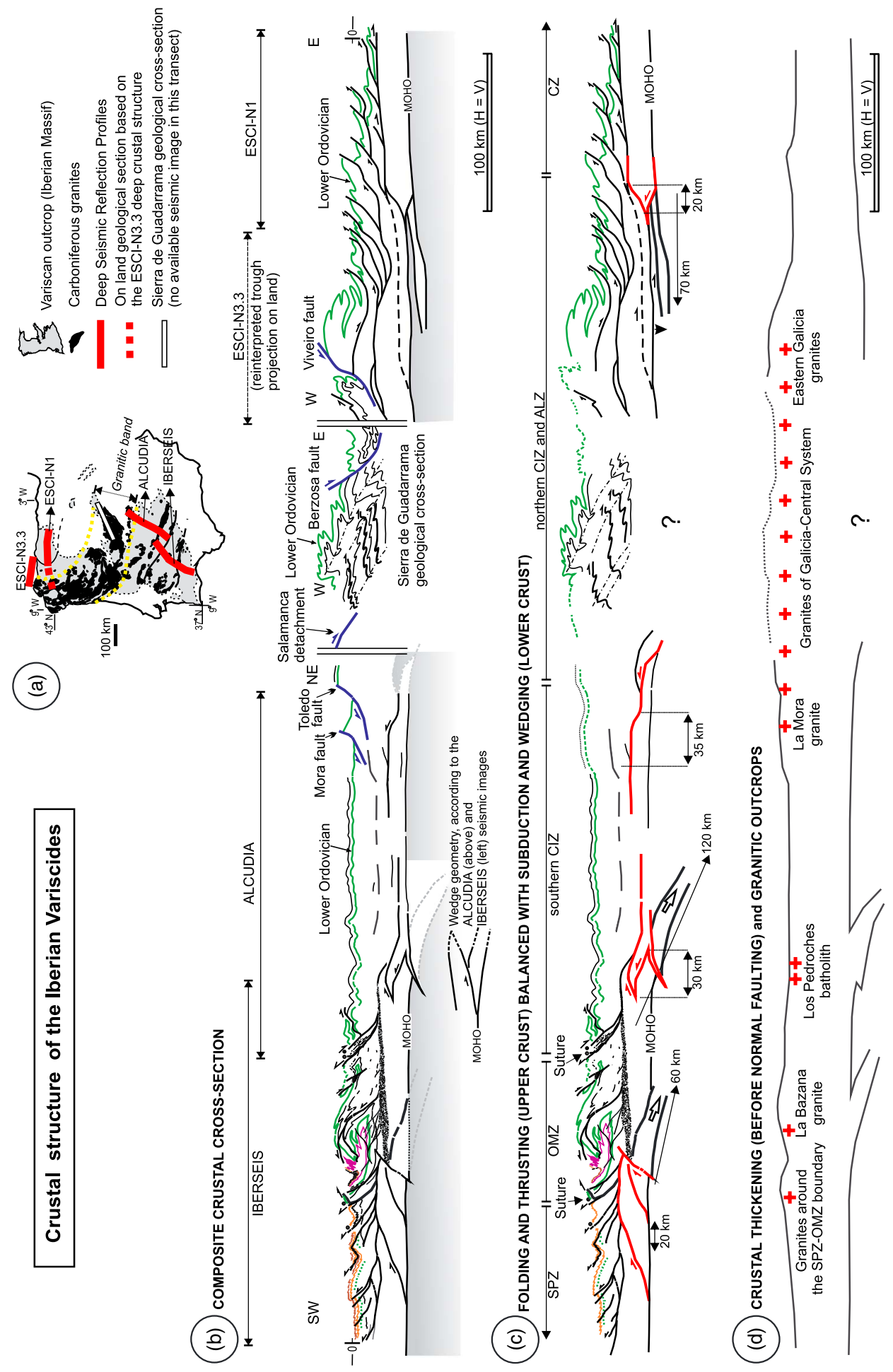




\section{Merging a Crustal Geotraverse of the Iberian Variscides}

[14] In order to build a 2-D crustal image of the Iberian Massif, we have integrated the available deep seismic transects into a single geotraverse. To do so, we have considered the following seismic profiles from south to north (Figure 2a): IBERSEIS [Simancas et al., 2003; Carbonell et al., 2004]; ALCUDIA [Martínez Poyatos et al., 2012]; ESCI-N3.2 and 3.3 [Martínez Catalán et al., 1995; Alvarez Marrón, 1996; Ayarza et al., 1998, 2004]; and ESCI-N1 [Pérez Estaún et al., 1994]. This set of seismic lines and their geological interpretation are displayed in Figure 2, though we refer the readers to the above-mentioned papers for the details of processing and interpretation of each particular profile. In the area covered by these seismic profiles, Alpine reactivation mostly consists in localized faulting, thus the merged section images a nearly complete crustal section of the frozen late orogenic Variscan structure (Figures $3 \mathrm{a}$ and $3 \mathrm{~b}$ ). The exceptions are the ESCI-N3.2 and 3.3 marine seismic profiles, which run E-W along the Cantabrian continental margin perpendicular to the strike of the Variscan structures, in an area affected by N-S Mesozoic crustal thinning and Alpine shortening. Mesozoic thinning is nevertheless negligible onshore in the Cantabrian region, and the Alpine shortening is concentrated in discrete crustal [Pulgar et al., 1995] and sub-Moho structures [Ayarza et al., 2004].

[15] Merging the available crustal seismic sections is an easy task in the case of the nearly continuous IBERSEIS and ALCUDIA profiles (Figure 2a). Actually, there is a satisfactory correlation of reflectors in the short segment where these two profiles structurally overlap. The reflectivity of the suture between the Ossa-Morena and Central Iberia zones is imaged in both sections dipping to the northeast, until it reaches a wedge-like structure in the lower crust (Figures 2d and 2e). Nevertheless, this wedge structure displays geometrical variations between the two profiles (Figures 2d, 2e, and 3b).

[16] The connection between ESCI-N1 and ESCI-N3.3 profiles is more complicated, since the former was recorded on land and the latter offshore (Figures $2 b$ and $2 c$ ). Despite the short distance between these two profiles, the ESCI-N3.3 line displays the image of a Variscan crust subsequently thinned during the Mesozoic evolution of the northern Iberia continental margin and affected by perpendicular Alpine compression in the Tertiary. Nevertheless, a reasonable identification of the main Variscan crustal structures was reached [Martinez Catalán et al., 1995], and a reconstructed thicker Variscan crust has been proposed according to the onshore geology (Figures 2c and 3b; Ayarza et al. [1998]). Westward, the seismic line ESCI-N3.2 (not displayed in Figure 2) exhibits a thinner crust with weak west-dipping upper crustal reflectors on its eastern side corresponding to arguable Variscan structures, a seismically transparent upper-middle crust that might reflect extensive Variscan crustal melting (see discussion later), and a thin and highly reflective seismic lower crust with a probably late Variscan Moho [Alvarez Marrón, 1996; Ayarza et al., 2004].

[17] The Iberian Variscan seismic geotraverse shows a gap between the ESCI-N3.2 and the ALCUDIA seismic profiles, corresponding to the Galicia-Central System band (Figure 3a). However, the Sierra de Guadarrama geological cross-section can be taken to partially fill this gap (Figure $3 \mathrm{~b}$ ). This cross-section in the interior of the Iberian Massif shows some features of particular relevance in the interpretation of the whole Variscan orogenic evolution, namely midcrustal Variscan stacking and exhumation of deep metamorphic rocks, including eclogites, which suggest intense deformation and thickening during the collisional deformation [Macaya et al., 1991; Barbero and Villaseca, 2000].

\section{Seismic Structure of the Iberian Variscan Crust}

[18] Significant seismic structures of the Iberian Variscan crust are reviewed here, though a more thorough discussion of each seismic line can be found in the papers referred above.

\subsection{Moho and Crustal Thickness}

[19] The Moho displayed in the interpreted seismic profiles is generally flat and located at between $9 \mathrm{~s}$ twoway-time (TWT) [ESCI-N3.2, Ayarza et al., 2004] and $12 \mathrm{~s}$ TWT [ESCI-N3.3], showing a fairly constant depth of $\sim 10 \mathrm{~s}$ TWT to the south (ALCUDIA and IBERSEIS sections, Figure 2). Flat Mohos imply the existence of late or post-orogenic processes that readjust the crust-mantle boundary topography. These processes may be related to sufficiently severe isostatic and thermal events [Cook,

Figure 3. (a) Sketch of the Iberian Variscan Massif highlighting the Carboniferous granites (black areas) and locating the seismic lines shown in Figure 2 (red lines) as well as the geological cross-section of Sierra de Guadarrama (white bar). Carboniferous granites concentrate in a central band (Galicia-Central System) not sampled by deep seismic reflection profiling, except at its boundaries. (b) Composite crustal cross-section of the Iberian Variscides, built from the available seismic and geological data (see discussion in the text). The geological cross-section of Sierra de Guadarrama (Central System) is after Macaya et al. [1991]. Note the presence of Late Carboniferous extensional detachments and high-angle faults (sketched with blue lines) in the Galicia-Central System Granitic band. (c) Balance of crustal collisional shortening. The geological assessment of deformation in the upper crust is compared and balanced with the seismically imaged structures in the lower crust (red and black thick lines). The abbreviations SPZ, OMZ, CIZ, ALZ, and CZ are as in Figure 1b. See text for discussion. (d) Approximate reconstruction of the Variscan crustal thickness of Iberia just before the crustal thinning due to extensional faults in northern Central Iberia. Note that the extensional faults have been approximately removed considering that they affect only the upper crust (i.e., no overall crustal extension). Thus, Figures $3 \mathrm{c}$ and $3 \mathrm{~d}$ do not differ in length. Red crosses indicate the location of granitic outcrops, to be compared with reconstructed crustal thickening. Note also the spatial correspondence between the region of Late Carboniferous granite concentration (this figure) and the region displaying extensional faults (Figure 3b). 
2002], which in the case of the Iberian Variscides might be Carboniferous-to-Permian isostatic rebound in response to tectonic thinning and erosion, and Permian thermal readjustments of the disturbed orogenic lithosphere. Moreover, in thermally mature crusts (as it was the case of some part of Central Iberia; see below) lateral flow of a lowviscous lower crust might have contributed to reducing crustal roots [Seyferth and Henk, 2004]. There are, however, some questions that need to be addressed, e.g., the differences in the crustal thickness and the existence of reflections entering the upper mantle, which have either survived to the late orogenic Moho resetting or represent a younger feature (see below).

\subsection{The Upper Crust}

[20] Most of the seismic geotraverse displays a reflective upper crust, with reflections that have been confidently related to outcropping Variscan structures (Figures 2b, 2c, $2 \mathrm{~d}$, and 2e). Nevertheless, the upper crust of the ALCUDIA line is rather transparent, probably due to the dominance of monotonous lithologies and weak deformation. The western part of the marine profile ESCI-N3.3 shows also a transparent upper crust (Figure 2c), as well as its western continuation (ESCI-N3.2), a feature that we interpret in connection with the appearance of granite outcrops. The first seconds of these two marine profiles correspond to Mesozoic basins.

\subsection{The Middle Crust}

[21] The middle crust of the ESCI-N1 and 3.3 lines shows subhorizontal or west-dipping weak reflections that are interpreted as the Cantabrian and West Asturian-Leonese zones basal decollements on the basis of their relation with the upper crust reflections. Similar reflections are found in the South Portuguese, the Ossa-Morena, and Central Iberian zones. In every case, these features delineate a subhorizontal boundary in the crust that, although located at different depths (from 4 to $8 \mathrm{~s}$ TWT), separates two areas of markedly different seismic signature and structure: the upper and lower crust.

[22] In addition, the middle crust of the Ossa-Morena zone is characterized by an approximately $150 \mathrm{~km}$ long band of high amplitude reflectivity, with variable thickness (up to $6 \mathrm{~km}$ ) and composed of lens-shaped interfingering reflection packages (Figure 2e). According to its reflective pattern and velocity and composition models [Palomeras et al., 2009, 2011; Brown et al., 2012], together with the geological context, this band has been interpreted as a sill-like complex of mafic/ultramafic rocks and interlayered metasediments. Mafic igneous bodies have also been proposed as source of conspicuous reflectivity in the upper crust of the adjacent South Portuguese zone [Schmelzbach et al., 2008].

\subsection{The Lower Crust}

[23] The seismic fabric of the lower crust features variations along the geotraverse. In the Cantabrian zone, the ESCI-N1 line shows poor reflectivity in the lower crust, except to the west where it features a few strong and relatively long reflections between 10 and 12 s TWT (Figure 2b). In the West Asturian-Leonese zone, the profile ESCI-N3.3 shows a thick (over $4 \mathrm{~s}$ TWT) deformed and highly reflective lower crust that contrasts with the thin and highly reflective lower crust observed westward, in the ESCI-N3.2 line. This change in the lower crust reflectivity is accompanied by an abrupt change in crustal thickness ( 9 to $12 \mathrm{~s}$ TWT), which suggests that both areas might have undergone different structural evolution, despite being in the same tectonic setting.

[24] Dipping bivergent subcrustal reflectors, probably of Alpine origin, are observed in the ESCI-N3.2 and 3.3 profiles. Additionally, the existence of a mantle layer tapering eastward and embedded into lower crustal rocks has been proposed (Figure 2c). The geological interpretation of this seismic structure is not clear, though it might correspond to underthrust of lower crustal rocks and/or a delamination process [Ayarza et al., 1998]. In its eastern tip, the embedded mantle connects with a wedge-like structure imaged in the lower crust of ESCI-N1 (Figure 3b).

[25] In the IBERSEIS profile, the lower crust displays mostly moderate reflectivity, and bright SW-dipping reflections are interpreted as discrete tectonic structures (Figure 2e). However, to its northern end, the lower crust appears to be more reflective, thicker, and clearly deformed. This is in agreement with the image that this part of the crust shows in the ALCUDIA line, where a pervasive and thick (up to $6 \mathrm{~s}$ TWT) subhorizontal seismic lamination contrasts with the rather transparent upper crust (Figure 2d). Lower crust seismic lamination has been related elsewhere to late orogenic extensional events [Meissner, 1999], but in the ALCUDIA profile, it is visibly disrupted by prominent contractive structures. Thus, the northern part of the ALCUDIA line exhibits in its lower crust a prominent pattern of reflectivity that has been interpreted as the ramp-and-flat geometry of a major shortening structure (Figures $2 \mathrm{~d}$ and $3 \mathrm{~b}$ ). Moreover, in the southern part of the ALCUDIA profile, a south-dipping reflection is observed penetrating into the mantle (Figure $2 \mathrm{~d}$ ). The pattern of reflectivity just above this reflection suggests the existence of a wedge-like shortening structure affecting the lower crust and the underlying mantle. This lower crust wedge was also found in the northern end of the IBERSEIS profile (Figure 2e), though showing opposite tapering directions (Figure $3 \mathrm{~b}$ ). The wedge cuts the reflectivity of the lower crust and generates antiformal folding of the overlying middle crust reflectivity. Furthermore, it originates at surface the tectonic inversion of Los Pedroches Lower Carboniferous basin.

[26] The IBERSEIS profile shows a discontinuous northdipping reflector in the middle crust deepening to the Moho, right where surface geology suggests subduction of the South Portuguese zone beneath the Ossa-Morena zone. Furthermore, this discontinuous reflector is truncated by the Moho (Figure 2e). Accordingly, we interpret this reflector as a trace of the subduction slab (Figures $3 \mathrm{~b}$ and $3 \mathrm{c}$ ).

\subsection{Crustal Decoupling}

[27] As described above, a decoupling between upper and lower crust is inferred throughout the Cantabrian (Figure 2b), West Asturian-Leonese (Figure 2c), southern Central Iberian (Figure 2d), Ossa-Morena, and South Portuguese zones (Figure 2e). The regional decoupling level in the South Portuguese and Ossa-Morena zones appears to root in suture boundaries (Figure 3b). In the Cantabrian zone, this decoupling level deepens in the lower crust under the West Asturian-Leonese zone and roots in the mantle layer underneath this zone (Figure 3b). Finally, in the internal zones, the rooting of the decoupling level cannot be tracked down: 
it deepens down to $8 \mathrm{~s}$ TWT in the western West AsturianLeonese zone (ESCI-N3.3) before (probably) merging with the crust-mantle boundary in line ESCI-N3.2, whereas under the Central Iberian zone this feature is not visible since the seismic images are too short (Figure 3b).

\section{Balancing Orogenic Shortening at Crustal Scale}

[28] A major issue in understanding orogenic processes concerns how deformation accommodates at lithospheric scale [e.g., Oldow et al., 1990; Quinlan et al., 1993; Harry et al., 1995; Pfiffner et al., 2000]. This section presents the balance of deformation at crustal scale, since this is the portion of the lithosphere that we can constrain from the seismic images. The basic principles of Balanced Geological Cross-Sections can be applied to the crustal/lithospheric scale, in order to test the orogenic deformational picture. To do that, we have to simplify deformation as approximately plane strain, i.e., no material movement out of the section plane. However, in the geotraverse across the Iberian Variscides, the lateral displacement of southwest Iberia with respect to central and northern Iberia cannot be ignored and will be discussed later.

[29] Orogenic shortening in the South Portuguese zone is estimated to be around $80 \mathrm{~km} \mathrm{(} \mathrm{45 \% ),} \mathrm{considering} \mathrm{the}$ geological section presented by Soriano and Casas [2002] and our unpublished section for the northernmost part of the zone. In the lower crust, imbricated structures represent only a minor contribution to crustal shortening (IBERSEIS section, Figure 2e), perhaps of no more than $20 \mathrm{~km}$. However, since the South Portuguese zone is bounded by a suture and upper and lower crust are visibly decoupled, subduction of the lower crust by an amount of $60 \mathrm{~km}$ would balance crustal shortening in this zone (Figure $3 \mathrm{c}$; note that we refer only to continental subduction of lower crust and not to previous oceanic subduction at this putative Rheic suture).

[30] Shortening of the upper crust in the Ossa-Morena zone has been evaluated at $120 \mathrm{~km}(\sim 57 \%)$, according to stratigraphic markers on the geological cross-section presented by Simancas et al. [2003]. As in the South Portuguese zone, subduction of the lower crust of the Ossa-Morena zone under the Central Iberian zone is suggested by the crustal structure in the ALCUDIA and IBERSEIS seismic profiles (Figure 3b), thus being the main way to balance the orogenic shortening at crustal scale (Figure $3 \mathrm{c}$ ).

[31] In the northern Iberian Variscides, the Cantabrian zone displays an imbricated thrust structure, the geological cross-section presented by Pérez Estaún et al. [1994] indicating an upper crust shortening of nearly $90 \mathrm{~km}(\sim 45 \%)$. The middle crust decoupling of the Cantabrian orogenic wedge suddenly deepens to the west under the Narcea antiform (Figure $2 b$ ), reaching the tip of the mantle taper envisaged by Ayarza et al. [1998] under the West Asturian-Leonese zone (Figures $2 \mathrm{c}$ and $3 b$ ). Based on the duplication of lower crustal reflectivity in this zone, we interpret here an intracontinental subduction that allowed balancing the crustal shortening through underthrusting of the Cantabrian zone lower crust, in a similar way to the South Portuguese and Ossa-Morena zone crusts. An orogenic contractional wedge in the lower crust represents a late $(20 \mathrm{~km})$ contribution to shortening (Figure $3 \mathrm{c}$ ).
Accordingly, in the Cantabrian, Ossa-Morena, and South Portuguese zones, the upper crust accommodates shortening through intense deformation, while the less deformed lower crust subducts/underthrusts the more internal zones to compensate global shortening. Thus, this mechanism has precluded the crust of these zones from suffering great thickening.

[32] In the West Asturian-Leonese zone, an upper crust shortening of around $125 \mathrm{~km}(\sim 68 \%)$ can be estimated from the geological cross-sections by Martínez Catalán et al. [2004]. The orogenic wedge in the upper crust of this zone displays frontal accretion to the east and basal accretion to the west [Pérez Estaún et al., 1991]. The lower crust is interpreted to have thickened too (Figure 2c; Martinez Catalán et al. [1995]), though decoupling along the middle crust suggests that crustal shortening is not totally balanced in situ (on the vertical), i.e., some rock mass has been transferred under the Central Iberian zone.

[33] The southern half of the Central Iberian zone underwent only moderate upper crustal shortening of about $65 \mathrm{~km}$, i.e., $\sim 30 \%$ (Figure 2d; Martínez Poyatos et al. [2012]). According to its seismic image, a thick band of conspicuous seismic lamination in the lower crust, representing pre-Pennsylvanian (most probably pre-Variscan) ductile deformation, appears deformed in two sectors near both ends of the profile, where shortening concentrates in two discrete structures. At the northeast end, a major thrust in the lower crust has been defined by a ramp-and-flat geometry, while near the southern end of the profile a wedge affecting the lower crust and the upper mantle is very apparent (Figures $2 \mathrm{~d}$ and $3 \mathrm{~b}$ ). The geometry of these two major structures let us estimate a shortening of $\sim 35 \mathrm{~km}$ for the thrust and at least $30 \mathrm{~km}$ for the wedge, i.e., these two structures concentrate the whole shortening of the overlying upper crust. Therefore, considering the part of the Central Iberian zone sampled by the ALCUDIA seismic profile, the orogenic shortening is balanced between the upper and the lower crust, though the mechanisms of deformation have been very different in each case: regular distribution by folding in the upper crust versus shortening concentrated in two major structures in the lower crust (Figure 3c).

[34] The gap in deep seismic information across the northern half of the Central Iberian zone hinders the discussion about the crustal structure in this segment of the Iberian geotraverse. However, there is evidence for the formation of a much thickened crust in this part of the orogen considering the following (Figure 3b): (i) the gap segment should be bounded to the northeast by a thickened crust, according to the interpretation of ESCI-N3.3 [Ayarza et al., 1998]; (ii) part of the deformation in the adjacent West AsturianLeonese zone is transferred toward this crust as discussed above; (iii) southwest of the seismic gap, at the northern end of the ALCUDIA profile, the crust shows structures that reveal significant previous thickening [Martínez Poyatos et al., 2012]; (iv) syn-orogenic normal faulting in the northern half of the Central Iberian zone [Hernández Enrile, 1991; Macaya et al., 1991; Pérez Estaún et al., 1991; Escuder Viruete et al., 1994, 1998; Díez Balda et al., 1995] suggests thinning of the upper crust of a thickened crust; and (v) metamorphic petrology documents exhumation of deep-seated rocks [Barbero and Villaseca, 2000; Rubio Pascual et al., 2013]. Hence, despite the lack of a seismic image, crustal 

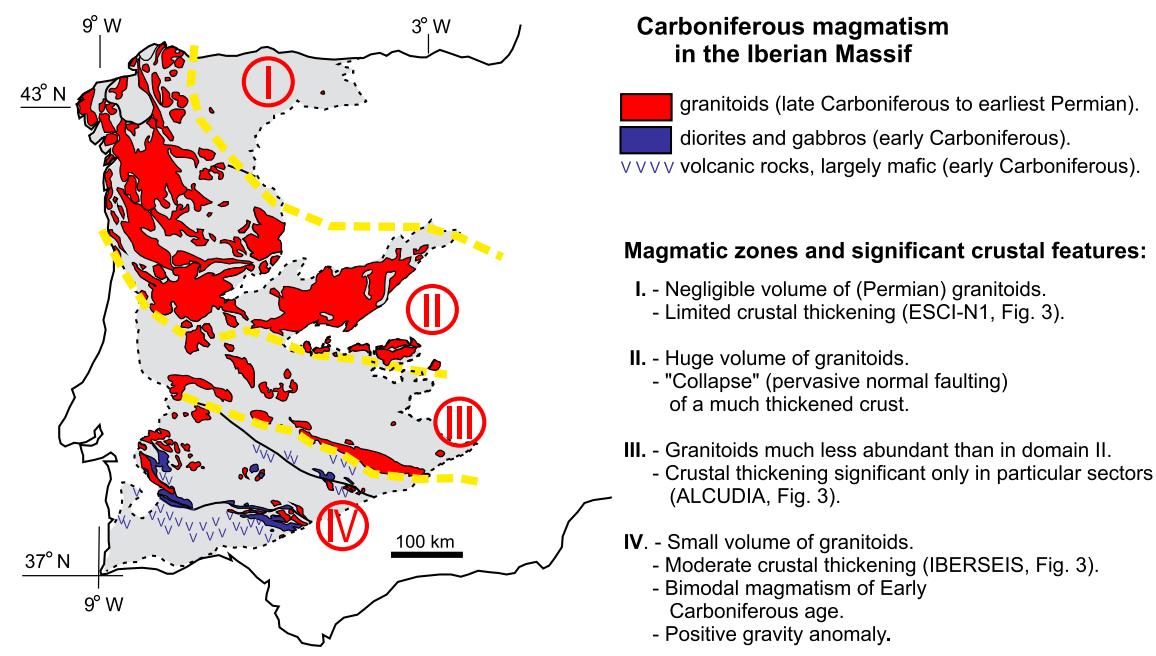

Figure 4. Zones of Carboniferous magmatism in the Iberian Variscides. Significant geological and crustal features of each magmatic zone are indicated in the figure and further explained in the text.

thickening should have been particularly important in this segment of the Central Iberian zone. Shortening of the upper crust was likely balanced here through coupled deformation (thickening) of the lower crust.

\section{Collisional Magmatism}

[35] The seismic crustal structure of Iberia summarized in previous sections suggests two modes of orogenic shortening: (i) the lower crust subducts or underthrusts by means of intracrustal detachment to compensate folding and thrusting in the upper crust, or (ii) the crust deforms as a whole. In the first case, the crustal thickening is moderate because the escaped lower crust does not contribute to thickening except where it underplates. On the other hand, if upper and lower crusts are coupled, then the whole crust contributes to orogenic thickening.

[36] Crustal thickening has been classically postulated as essential for crustal melting in continental collision zones [e.g., England and Thompson, 1986]. The structure of the Iberian Variscides described in this work offers a good opportunity to check this hypothesis by comparing granitic magmatism and crustal structure.

\subsection{Orogenic Magmatism in the Iberian Variscides}

[37] We deal here with the syn-orogenic to late orogenic Carboniferous magmatism, overwhelmingly represented by granitoids [e.g., Bea, 2004] except in southwest Iberia. It can be analyzed considering four distinctive magmatic zones (Figure 4).

[38] Magmatic zone I includes the Cantabrian and most of the West Asturian-Leonese zones (Figure 4), being characterized by the outcrop of a negligible volume of Early Permian stocks of calc-alkaline to shoshonitic affinity, which represent post-orogenic magmatism.

[39] Magmatic zone II includes the westernmost West Asturian-Leonese zone and the northern half of the Central Iberian zone, where large volumes of 320-300 Ma granitoids exist (Bea [2004]; Valle Aguado et al. [2005]; Orejana et al. [2012]; Figure 4). Nevertheless, anatexis started earlier ( $330 \mathrm{Ma})$ at some migmatitic complexes [Montero et al.,
2004; Bea et al., 2006; Castiñeiras et al., 2008]. Almost all of these granitoids display isotopic signatures supporting derivation from recycled metasedimentary and metaigneous sources in the continental crust [Villaseca et al., 1998, 2012; Bea et al., 2003; Orejana et al., 2012], though varying degrees of involvement of mantle-derived melts have been invoked for some of them [Fernández Suárez et al., 2000].

[40] Magmatic zone III corresponds essentially to the southern half of the Central Iberian zone, where granitoids are much less abundant than in zone II (Figure 4).

[41] Finally, magmatic zone IV includes the South Portuguese and Ossa-Morena zones (Figure 4), being characterized by mafic Carboniferous magmatism. Two magmatic episodes can be distinguished in this magmatic zone. The first one, Early Carboniferous in age (350-335 Ma; Azor et al. [2008]; Pin et al. [2008]; Valenzuela et al. [2011]), is bimodal (basalts, gabbros, rhyolites, and granites; Schermerhörn [1975]) and associated with normal faulting and basin formation, thus being interpreted as a transient rifting stage not found elsewhere in the Iberian Massif. Interestingly, a great volume of mafic rocks may have been imaged in the middle crust [Simancas et al., 2003; Carbonell et al., 2004; Schmelzbach et al., 2008; Palomeras et al., 2011; Brown et al., 2012]. The second magmatic episode is represented by a negligible volume of Late Carboniferous collisional granitoids.

\subsection{Role of Crustal Thickening}

[42] The abundance and distribution of granitoids in the Iberian Massif can now be examined in light of the crustal structure. Since the orogenic belt is not expected to keep all its features along strike, we will compare the crustal structure with the granitic outcrops crossed by seismic lines.

[43] The lack of collisional granitoids in the Cantabrian zone and the eastern part of the West Asturian-Leonese zone (magmatic zone I; Figure 4) reflects the limited crustal thickening due to lower crustal decoupling (Figures $3 \mathrm{c}$ and $3 \mathrm{~d}$ ). On the contrary, in the western West Asturian-Leonese zone (included in the magmatic zone II of Figure 4), granitoids are abundant where surface geology points to a much thickened Variscan crust before subsequent thinning [Pérez Estaún et al., 1991]. 


\section{SIMANCAS ET AL.: SEISMIC GEOTRAVERSE IBERIAN VARISCIDES}

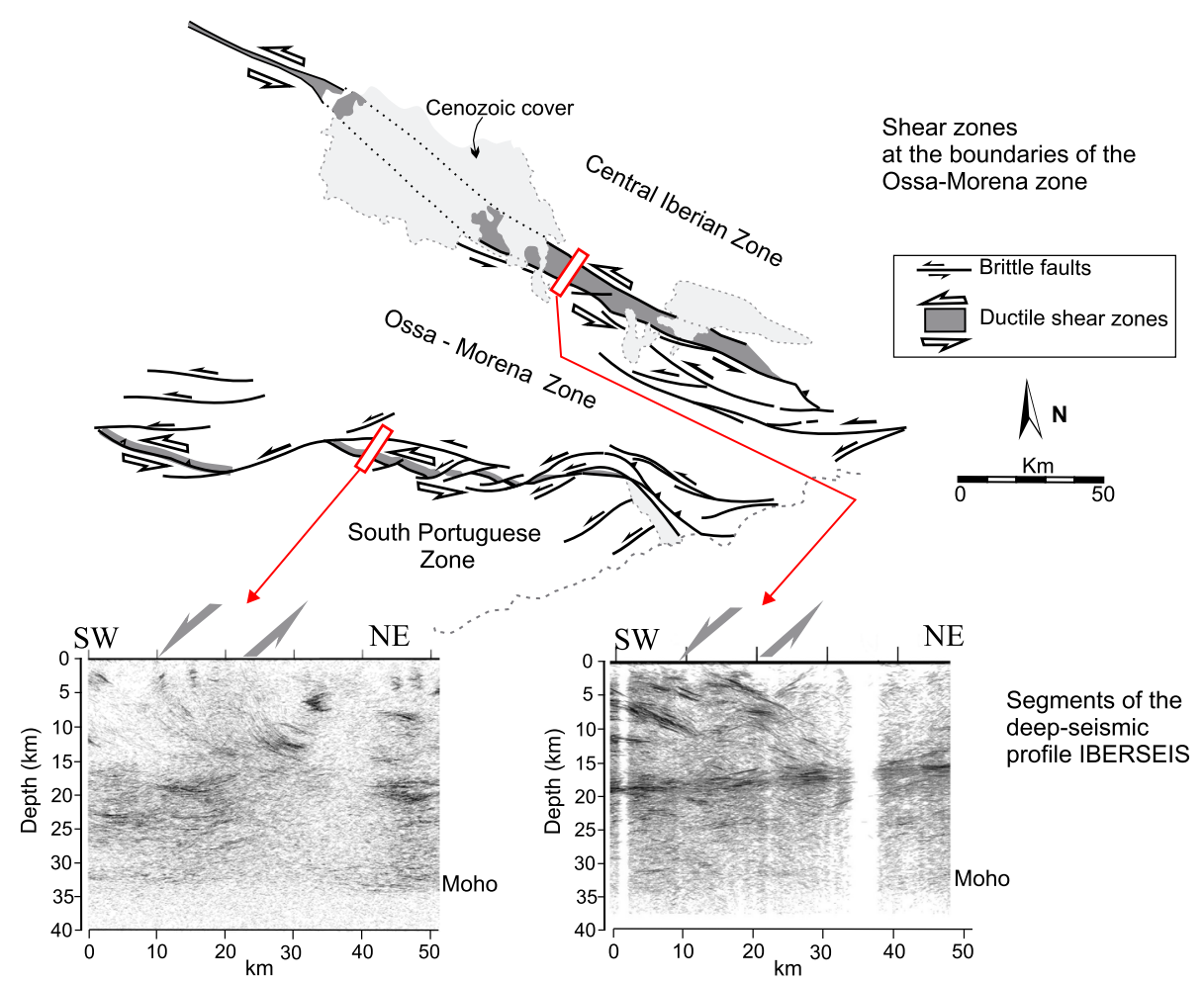

Figure 5. Left-lateral shear zones featuring the collisional evolution of the Ossa-Morena Zone boundaries (see text for further details). The seismic expression of these shear zones down to the middle crust in the IBERSEIS profile is shown.

In agreement with the granitic abundance, the western part of the marine seismic profile ESCI-N3.3 shows a nonreflective upper-middle crust (Figure 2c; Martínez Catalán et al. [1995]). A seismically transparent (granite rich?) crust is also observed in the ESCI-N3.2 line west of ESCI-N3.3, which is not displayed in Figure 2 [Ayarza et al., 2004].

[44] Late Carboniferous granitoids permeate the northern half of the Central Iberian zone (zone II, Figure 4). Unfortunately, the crustal structure of this region has been seismically imaged only at its boundaries (Figures $3 a$ and $3 b$ ). However, geological data point to a thickened Variscan crust [Barbero and Villaseca, 2000]. Accordingly, a correlation is suggested to exist between granitic production and crustal thickening (Figure 3d).

[45] The southern half of the Central Iberian zone sampled by the ALCUDIA seismic profile (zone III, Figure 4) presents granitic outcrops only at both ends, where important crustal thickening occurred during the Variscan collision. Toward the south, granites do not crop out for some distance, in correlation with the seismic image of a nonthickened crust. At the southernmost sector, the Pedroches batholith [Carracedo et al., 2009] is underlain by a conspicuous Variscan wedge structure responsible for significant crustal thickening (Figures 3b, 3c, and 3d). Furthermore, the Ossa-Morena lower crust subducted underneath the southern Central Iberian zone might have also contributed to crustal thickening here.

[46] Finally, the meager volume of collisional granitoids in southwest Iberia (zone IV, Figure 4) is consistent with the subduction of its lower crust under the sutures located at both boundaries of the Ossa-Morena zone, which restricts crustal thickening to the sectors overlying underplated crust. The spatial correlation between these sectors and the localized outcrops of collisional granitoids in zone IV is good (Figures $3 \mathrm{c}$ and $3 \mathrm{~d}$ ).

\section{Out-of-Section Displacements}

[47] Major strike-slip displacements have been reported in the Iberian Variscides, mostly in the northern and southern boundaries of the Ossa-Morena zone [Burg et al., 1981; Crespo Blanc y Orozco, 1988; Azor et al., 1994]. Moreover, tectonic models consider the evolution of a curved orogen [e.g., Matte, 1986; Simancas et al., 2005; Ribeiro et al., 2007; Martínez Catalán, 2011]. These arguments hinder a simple 2-D interpretation represented by a geotraverse (crustal section), making it necessary to include the kinematics of the orogen in map view. However, out-of-section displacements are not completely independent, and the crustal structure imaged in the seismic geotraverse puts some constraints, as will be discussed in the following. Again, we will limit the discussion to crustal deformation, because the way lithospheric mantle behaves during orocline formation is not constrained by our geological and seismic data (but see Gutiérrez-Alonso et al. [2004]).

\subsection{Left-Lateral Shear Zones}

[48] The most important across-section displacements in the Iberian geotraverse are located at the two suture boundaries of the Ossa-Morena zone (Figures $1 \mathrm{~b}$ and 5). They are represented by major ductile-to-brittle left-lateral shear zones with steeply dipping mylonitic foliation and 


\section{The Variscan Iberian Orocline}

(a) Geometry of the orocline

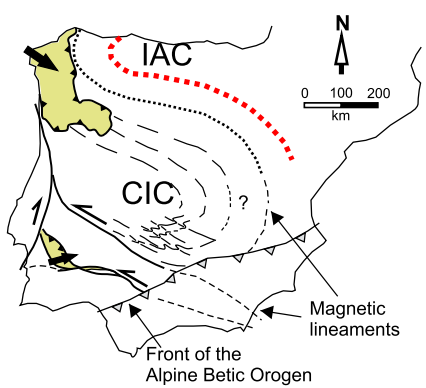

(b) The dextral megashear model (simplified from Martinez Catalán, 2011)

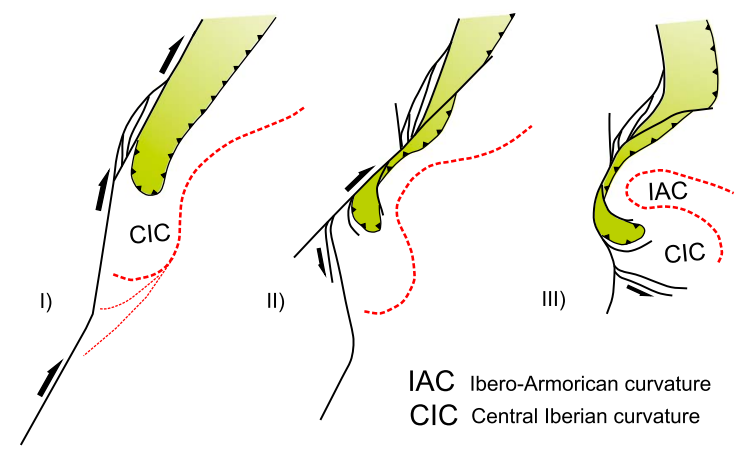

(c) Model of indentation and left-lateral shearing
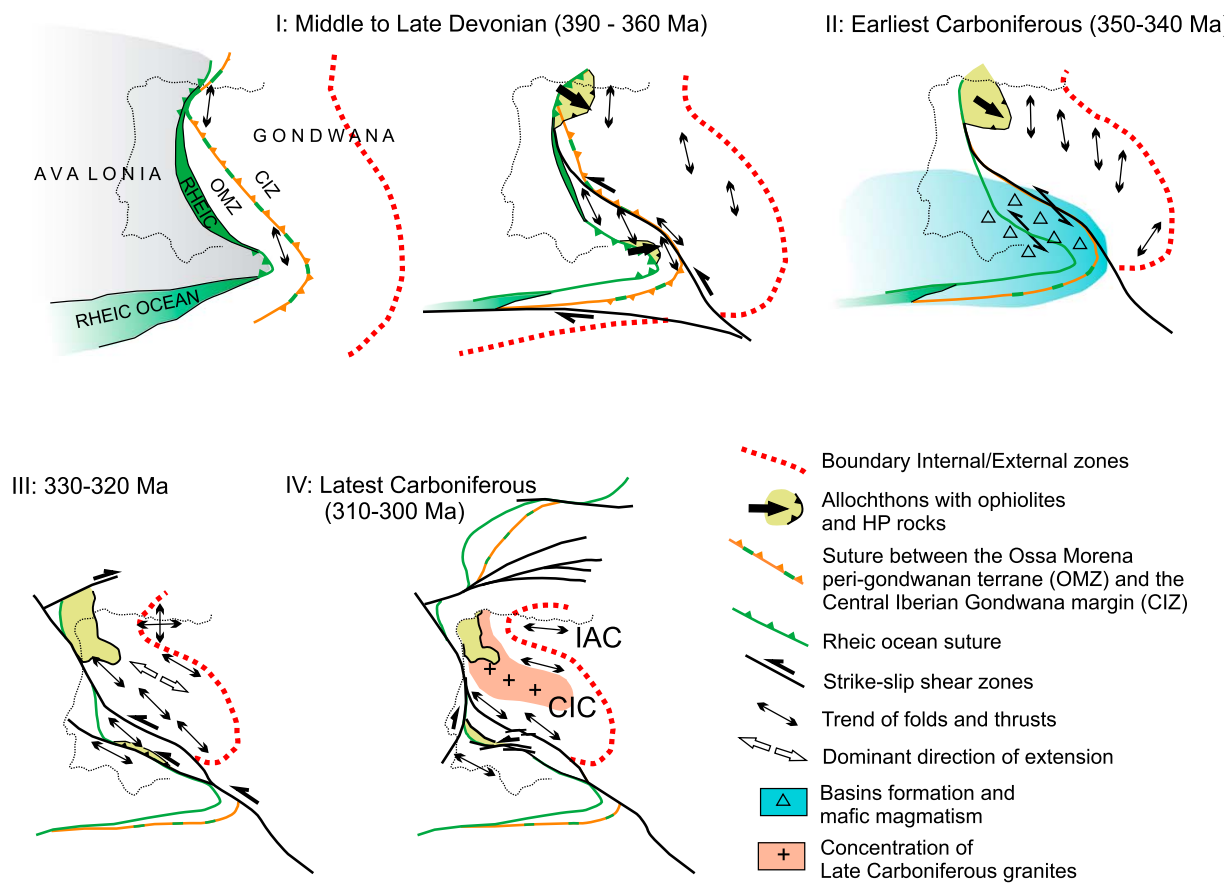

Figure 6. (a) The S-shaped Iberian Variscan Orocline (modified from Martínez Catalán [2012]). IAC $=$ Ibero-Armorican curvature; $\mathrm{CIC}=$ Central Iberian curvature. The dotted red line marks the boundary between external and internal zones of the orogen. (b) Kinematic model for the Iberian orocline, based on the existence of a hypothetical dextral megashear zone dragging most of the Iberian Massif [Martinez Catalán, 2011, 2012]. (c) Alternative kinematic model for the Iberian orocline proposed in this paper (see text for discussion).

horizontal or low-pitch stretching lineations. The total slip along these major shear zones cannot be precisely established, i.e., the relatively minor brittle (late) displacements are estimated to be 80-90 km [e.g., Jackson and Sanderson, 1992], but the much greater ductile synmetamorphic displacements are elusive [Burg et al., 1981; Crespo-Blanc, 1992; Azor et al., 1994]. The southern Ossa-Morena shear zone exhibits only midcrustal rocks at surface, but the northern one exhumed eclogites with estimated peak-pressure around $19 \mathrm{kbar}$ at a temperature of about $550^{\circ} \mathrm{C}$, which are conditions characteristic of a subduction environment [López Sánchez-
Vizcaino et al., 2003]. These major shear zones obliterate the previous subduction boundaries of the Ossa-Morena zone, thus representing the collisional evolution of these sutures. According to the IBERSEIS seismic profile, both shear zones dip to the N-NE until they reach the middle crust (Simancas et al. [2003]; Kashubin and Juhlin [2010]; Figures 2e and 5). Their continuation into the lower crust is not evident in the seismic image. Our suggestion is that they were strongly controlled by preexisting anisotropies, thus penetrating the lower crust following closely the trajectories of the suture boundaries (Figure 3c). 


\subsection{The Iberian Variscan Orocline}

[49] The western Variscides show an orocline configuration whose major curvature, the so-called Ibero-Armorican arc, includes French and Iberian outcrops [e.g., Matte, 1986]. To the south, a second curvature of the Iberian Variscides has been recognized through careful inspection of previously overlooked features such as structural alignments and magnetic anomalies under the post-Palaeozoic cover [Aerden, 2004; Martínez Catalán, 2011; 2012; Shaw et al., 2012]. This southern oroclinal curvature cores in the Central Iberian zone. Altogether the Ibero-Armorican and the Central Iberian curvatures define an S-shaped orogenic belt (Figure 6a).

[50] The Ibero-Armorican curvature is a major feature of the Variscan belt (Figure 1a). Its hinge and maximum tightness are located in the Cantabrian zone of Iberia, which displays crossed folds and a converging pattern of thrust vectors [Pérez Estaún et al., 1988]. The orocline was originally explained by indentation of an Iberian block [Matte and Ribeiro, 1975] or as a "corner effect" [Brun and Burg, 1982]. However, palaeomagnetic data lend support to a rather late growth of the curvature in Late CarboniferousEarly Permian times, thus suggesting folding of a Carboniferous linear belt by late north-south (present coordinates) shortening [Weil et al., 2000]. The midcrustal decoupling level seismically imaged under the Cantabrian zone and its westward deepening (Figures $2 b$ and $3 b$ ) would imply that to the west progressively deeper crust was involved in the orocline structure. Furthermore, this decollement suggests that either the underlying lower crust and lithospheric mantle were not involved in the Ibero-Armorican curvature, or at least they folded disharmonically with respect to the overlying crust.

[51] The Central Iberian curvature is $\sim 300 \mathrm{~km}$ wide (Figure 6a), whose formation has been related to a dextral strike-slip megashear zone, either as a fault-propagation fold or a drag-fold [Martínez Catalán, 2011, 2012] (Figure 6b). However, the large dimensions of this curvature hinder this mechanism. This difficulty becomes insurmountable when the seismically revealed features of the lower crust in southern Central Iberia (ALCUDIA seismic profile) are taken into account, namely the existence of a decoupling at the middle crust and a mechanically strong lower crust. Accordingly, an alternative model for the origin of the Iberian Variscan orocline will be discussed in the next section.

\section{Discussion}

[52] The crustal-scale Iberian geotraverse of the Variscan belt (Figure 3) prompts a discussion of important topics regarding the orogenic evolution, such as accommodation of collisional shortening, relationships between crustal thickening and granitic magmatism, and orocline formation.

\subsection{Modes of Orogenic Shortening}

[53] Different modes of orogenic shortening are represented in the Iberian geotraverse of the Variscides. The fundamental distinction is between coupled and uncoupled deformation of upper and lower crust. Uncoupling is favored by the following: (i) the existence of a mechanical anisotropy separating a weaker upper crust from a generally more resistant lower crust and (ii) the connection with a suture zone where lower crust may subduct. Rheologically, the midcrustal decollement may correspond to the strength weakening of the brittle-ductile transition, as shown in many strength-depth theoretical profiles [e.g., Ranalli and Murphy, 1987].

[54] In regions where crustal uncoupling applies, subduction/ underthrusting of the lower crust is the dominant way to compensate shortening of the upper crust. This mechanical behavior does not produce great crustal thickening, as exemplified in the South Portuguese, Ossa-Morena (IBERSEIS seismic profile) and Cantabrian zones (ESCI-N1 seismic profile). However, crustal thickening is significant where the escaped lower crust underthrust. This was the case of the sutures in southwest Iberia (IBERSEIS seismic profile, Figure 3c). In a similar way, crustal thickening under the West Asturian-Leonese zone is explained by underthrusting of the Cantabrian lower crust under the West Asturian-Leonese zone, which might imply additional thickening of $10 \mathrm{~km}$ (Figures $3 \mathrm{~b}$ and $3 \mathrm{c}$ ).

[55] In terms of crustal coupling/uncoupling during orogenic deformation, an intermediate situation is found where the lower crust is mechanically strong and cannot easily subduct. In this case, only moderate crustal shortening is reached due to the difficulty of the lower crust to deform. Furthermore, the mechanical differences between upper and lower crust are displayed in different modes of deformation: a regular distribution by folding and thrusting in the upper crust versus shortening in few discrete structures in the lower crust. Clearly, some decoupling between the upper and the lower crust is still required. This is the type of deformation envisaged in the southern half of the Central Iberian zone (ALCUDIA seismic profile, Figure 3c).

[56] The best scenario for coupled crustal deformation is a relatively weak lower crust unconnected with a suture where it might subduct/underthrust. The consequence is widespread crustal thickening, since the whole crust contributes to it, as in the case of the northern Central Iberian zone. The keys behind the suspected weak behavior of the lower crust in this region are not evident, but a favoring factor might be the rather felsic composition inferred from the nature of granulitic xenoliths in Central Spain [Villaseca et al., 1999].

\subsection{Crustal Thickening, Granitic Magmatism, and Normal Faulting}

[57] Factors such as crustal thickening, water availability, fertility of lithologies at the source, and heat provided by magmas from the mantle are expected to influence crustal melting. However, the relative importance of these factors is uncertain. For instance, underplated or intraplated mafic magmas are commonly invoked to explain voluminous granitic magma production [Clemens, 2005], though numerical modeling supports the effectiveness of crustal thickening and radiogenic heating [Bea, 2012].

[58] Crustal thickening has been determinant in generating collisional magmatism in Iberia. In regions where the lower crust has subducted, granitic outcrops are minor and correlate with localized sectors where the lower crust underthrusts. On the contrary, voluminous granitic magmatism is related to a crust broadly thickened because of difficult subduction and coupled crustal deformation (Figure $3 \mathrm{~d}$ ). In addition, a fertile composition of the lower crust would facilitate melting [Orejana et al., 2011; Bea, 2012; Villaseca et al., 2012]. Convective heat from mantle-derived magmas can be minimized in view of the 
scarcity of mafic rocks and the felsic nature of most granulitic xenoliths in Central Iberia [Villaseca et al., 1999, 2012; Bea et al., 2003; Bea, 2004]. In this respect, it is worth emphasizing that where granitoids and mafic rocks spatially coexist, the age of the latter is younger than the beginning of crustal melting [Fernández Suárez et al., 2000; Bea et al., 2006].

[59] An old (around $350 \mathrm{Ma}$ ) limited melting episode has been reported in Central Iberia [Montero et al., 2004]. Apart from this, the first widespread evidence of crustal melting are migmatite complexes dated at around $330 \mathrm{Ma}$ [Montero et al., 2004, Bea et al., 2006, Castiñeiras et al., 2008] and synkinematic granitoids of $325 \mathrm{Ma}$ [Fernández Suárez et al., 2000]. Afterward, massive production of granitoids took place in Central Iberia until $295 \mathrm{Ma}$. We interpret this magmatic evolution as a consequence of the progressive thermal maturity of the thickened crust.

[60] Normal faults spatially and temporally associated with crustal melting in Central Iberia produced orogen-parallel extension of the upper crust (Figure 3b) [Escuder Viruete et al., 1994; Díez Balda et al., 1995; Rubio Pascual et al., 2013]. Extensional detachments are associated with migmatite complexes and early granitoids of 330-325 Ma, dating of extensional fabrics having yielded this same age range [Valverde Vaquero et al., 1995]. These detachments are affected by open folds, though later normal faults testify that extension and shortening events continued until the end of the Carboniferous [e.g., Fernández Suárez et al., 2000; Rubio Pascual et al., 2013].

[61] The extension in the northern half of Central Iberia occurred simultaneously with shortening in other sectors of the orogen. This suggests that the tectonic pattern would be controlled by compressional horizontal forces induced by collision rather than gravitational instability of the thickened crust. In this context, theoretical models [Royden, 1996; Seyferth and Henk, 2004] indicate that beneath the areas of extension in the upper crust, shortening may prevail in the lower crust. This would be an efficient mechanism for exhumation of granulites and eclogites in northern Central Iberia [Barbero and Villaseca, 2000].

[62] The magmatism of southwest Iberia (magmatic zone IV in Figure 4) is a different case compared to the one in Central Iberia. It is characterized by bimodal magmatism (largely mafic) of earliest Carboniferous age, and mafic magmas are here the key to interpret coeval crustal melting [e.g., Schermerhörn, 1975; Valenzuela et al., 2011]. The tectonic context of this magmatism and the associated sedimentary basins is an intraorogenic extensional event of arguable origin [Simancas et al., 2006]. Subsequently, at Late Carboniferous time, small volumes of collisional granites were produced at localized sectors of thickened crust (Figure 3d).

\subsection{The Formation of the Iberian Variscan Orocline}

[63] The Ibero-Armorican and the Central Iberian curvatures define an S-shaped orocline (Figure 6a). As regards the Ibero-Armorican curvature, palaeomagnetic data indicate late folding of a linear belt [Weil et al., 2000], having been proposed that folding involved simultaneously crust and lithospheric mantle [Gutiérrez-Alonso et al., 2004]. However, the west-dipping decollement seismically imaged under the Cantabrian and West Asturian-Leonese zones (Figures $2 \mathrm{~b}$ and $3 \mathrm{~b}$ ) indicate that lower crust and lithospheric mantle were not fully involved in the IberoArmorican curvature.

[64] The Central Iberian curvature has been related to a dextral strike-slip megashear zone [Martínez Catalán, 2011, 2012] (Figure 6b). Nevertheless, the envisaged drag is mechanically difficult and hardly compatible with the revealed features of the lower crust in southern Central Iberia (ALCUDIA seismic profile; Figure 2d). Moreover, the drag-fold model would require a strong shear strain that is not identified at surface. Last but not least, structural data supporting the invoked dextral strike-slip megashear zone lack in southern Iberia. Instead, a continuous record of leftlateral oblique displacements characterizes SW Iberia since the start of the Variscan collision at middle Devonian time, until the end of the convergence in late Carboniferous times [Burg et al., 1981; Crespo Blanc and Orozco, 1988; Azor et al., 1994; Simancas et al., 2001; Pereira et al., 2008; Ponce et al., 2012]. Thus, an alternative model is proposed here, in which the curvatures of the Iberian Variscides nucleated around palaeogeographic salients and were enhanced during the Variscan collision.

[65] The alternative tectonic evolution can be summarized as follows (Figure 6c): (i) the southern curvature of the S-shaped Iberian orocline was originally a bend molded around an Avalonian salient, currently represented in the South Portuguese zone (Figures 1a and 6c stage I); (ii) the left-lateral major shear zones of SW Iberia cut the bend and translated it to the NW, whereas transpressive rightlateral shearing in the French Variscides contributed to the inception of the Ibero-Armorican curvature (Figure 6c, stages I-III); (iii) finally, the two curvatures of the Iberian Variscan orocline were significantly tightened by northsouth shortening in latest Carboniferous time (Figure 6c, stage IV). This model accounts for the following geological and geophysical features: (i) it is compatible with decoupled upper and lower crusts; (ii) it accommodates the inferred location of the Rheic suture in southwest and northwest Iberia; and (iii) it reproduces the kinematics and timing of the Variscan deformations in Iberia, enhancing the role of conspicuous left-lateral shearing in SW Iberia, in contrast to the prevailing right-lateral kinematics in the neighboring regions of France and Morocco.

\section{Conclusions}

[66] Different modes of orogenic shortening have been revealed in the Iberian geotraverse of the Variscides, which are characterized by variable coupling of upper and lower crust. (i) In some areas, subduction/underthrusting of the lower crust is the dominant way to compensate shortening of the upper crust. This mechanical behavior does not produce great crustal thickening except where the escaped lower crust underthrust. (ii) In other areas, the lower crust is mechanically strong and cannot easily subduct, which results in modest crustal shortening. Deformation is partitioned into regular folding in the upper crust and major faults in the lower crust, with some decollement in-between. (iii) Finally, coupled crustal deformation takes place when a relatively weak lower crust exists and is unconnected with a suture where it might subduct. The consequence is important crustal thickening. 
[67] Crustal thickening has been determinant in generating collisional magmatism. The voluminous granitic magmatism of northern Central Iberia is related to a crust broadly thickened because of coupled crustal shortening. On the contrary, the bimodal magmatism that dominates SW Iberia represents a previous (Early Carboniferous) transient extensional event.

[68] Normal faults developed in northern Central Iberia associated to crustal melting, giving way to orogen-parallel extension of the upper crust. Extension occurred simultaneously with shortening in other sectors of the orogen, thus suggesting that compressional horizontal forces prevailed over gravitational forces. Shortening seems to prevail in the lower crust beneath the extending upper crust, which would constitute an efficient syncollisional mechanism for exhumation in this central part of the orogen.

[69] The Iberian Variscides record important lateral displacements, concentrated in the two suture boundaries of the OssaMorena zone. These major shear zones obliterate previous subduction boundaries, thus representing the collisional evolution of these sutures. They translated to the NW an early orogenic bend fold originated by the impingement of an Avalonian salient, at present represented by the South Portuguese zone.

[70] Acknowledgments. Funding for this research has been provided by the Spanish Ministry of Science and Innovation (grants: CGL2004-04623/ BTE, CGL2007-63101/BTE, CGL2011-24101, and CSD2006-00041). We acknowledge J. P. Burg and an anonymous reviewer for helping us to improve clarity of exposition.

\section{References}

Aerden, D. G. M. A. (2004), Correlating deformation in Variscan NW Iberia using porphyroblasts; implications for the Ibero-Armorican Arc, J. Struct. Geol., 26, 177-196.

Alvarez Marrón, J., et al. (1996), Seismic structure of the northern continental margin of Spain from ESCIN deep seismic profiles, Tectonophysics, 264, 153-174.

Arenas, R., J. R. Martínez Catalán, and F. Díaz García (2004), Zona de Galicia-Trás-Os-Montes, in Geología de España, edited by J. A. Vera, pp. 133-165, SGE-IGME, Madrid.

Ayarza, P., J. R. Martínez Catalán, J. Gallart, J. J. Dañobeitia, and J. A. Pulgar (1998), Estudio Sísmico de la Corteza Ibérica Norte 3.3: A seismic image of the Variscan crust in the hinterland of the NW Iberian Massif, Tectonics, 17, 171-186.

Ayarza, P., J. R. Martínez Catalán, J. Alvarez-Marrón, H. Zeyen, and C. Juhlin (2004), Geophysical constraints on the deep structure of a limited ocean-continent subduction zone at the North Iberian Margin, Tectonics, 23, TC1010, doi:10.1029/2002TC001487.

Azor, A., F. González Lodeiro, and J. F. Simancas (1994), Tectonic evolution of the boundary between the Central Iberian and Ossa-Morena zones (Variscan belt, southwest Spain), Tectonics, 13, 45-61.

Azor, A., D. Rubatto, J. F. Simancas, F. González Lodeiro, D. Martínez Poyatos, L. M. Martín Parra, and J. Matas (2008), Rheic Ocean ophiolitic remnants in southern Iberia questioned by SHRIMP U-Pb zircon ages on the Beja-Acebuches amphibolites, Tectonics, 27, TC5006, doi:10.1029/ 2008TC002306.

Azor, A., D. Rubatto, C. Marchesi, J. F. Simancas, F. González Lodeiro, D. Martínez Poyatos, L. M. Martín Parra, and J. Matas (2009), Reply to comment by C. Pin and J. Rodríguez on "Rheic Ocean ophiolitic remnants in southern Iberia questioned by SHRIMP U-Pb zircon ages on the Beja-Acebuches amphibolites", Tectonics, 28, TC5014, doi:10.1029/ 2009 TC002527.

Barbero, L., and C. Villaseca (2000), Eclogite facies relicts in metabasites from the Sierra de Guadarrama (Spanish Central System): P-T estimations for the Hercynian evolution, Mineral. Mag., 64, 815-836.

Bea, F. (2004), La naturaleza del magmatismo de la Zona Centroibérica: Consideraciones generales y ensayo de correlación, in Geología de España, edited by J. A. Vera, pp. 128-133, SGE-IGME, Madrid.

Bea, F. (2012), The sources of energy for crustal melting and the geochemistry of heat-producing elements, Lithos, 153, 278-291.

Bea, F., P. Montero, and T. Zinger (2003), The nature, origin and thermal influence of the granite source layer of Central Iberia, The J. Geol., 111, 579-595.
Bea, F., P. Montero, F. González-Lodeiro, C. Talavera, J. F. Molina, J. H. Scarrow, M. J. Whitehouse, and T. Zinger (2006), Zircon thermometry and $\mathrm{U}-\mathrm{Pb}$ ion-microprobe dating of the gabbros and associated migmatites of the Variscan Toledo Anatectic Complex, Central Iberia, J. Geol. Soc. London, 163, 847-855.

Brown, L. D., C. Ando, S. Klemperer, J. Oliver, S. Kaufman, B. Czuchra, T. Walsh, and Y. W. Isachsen (1983), Adirondack-Appalachian crustal structure: The COCORP northeast traverse, Geol. Soc. Am. Bull., 94, 1173-1184.

Brown, D., X. Zhang, I. Palomeras, F. Simancas, R. Carbonell, C. Juhlin, and M. Salisbury (2012), Petrophysical analysis of a mid-crustal reflector in the IBERSEIS profile, SW Spain, Tectonophysics, 550-553, 35-46, doi:10.1016/j.tecto.2012.05.004.

Brun, J. P., and J. P. Burg (1982), Combined thrusting and wrenching in the Ibero-Armorican arc: A corner effect during continental collision, Earth Planet. Sci. Lett., 61, 319-332.

Burg, J. P., M. Iglesias, P. Laurent, P. Matte, and A. Ribeiro (1981), Variscan intracontinental deformation: The Coimbra-Badajoz shear zone (SW Iberian Peninsula), Tectonophysics, 78, 161-177.

Carbonell, R., J. F. Simancas, C. Juhlin, J. Pous, A. Pérez Estaún, F. González Lodeiro, G. Muñoz, W. Heise, and P. Ayarza (2004), Geophysical evidence of a mantle derived intrusion in SW Iberia, Geophys. Res. Lett., 31, L11601, doi:10.1029/2004GL019684.

Carracedo, M., J. L. Paquette, A. Alonso Olazabal, J. F. Santos Zalduegui, S. García de Madinabeitia, M. Tiepolo, and J.L. Gil Ibarguchi (2009), $\mathrm{U}-\mathrm{Pb}$ dating of granodiorite and granite units of the Los Pedroches batholith. Implications for geodynamic models of the southern Central Iberian Zone (Iberian Massif), Int. J. Earth Sci. (Geol. Rundsch), 98, 1609-1624.

Castiñeiras, P., C. Villaseca, L. Barbero, and C. Martín Romera (2008), SHRIMP $\mathrm{U}-\mathrm{Pb}$ zircon dating of anatexis in high-grade migmatite complexes of Central Spain: Implications in the Hercynian evolution of Central Iberia, Int. J. Earth Sci. (Geol Rundsch), 97, 35-50.

Clemens, J. D. (2005), Melting of the continental crust: Fluid regimes, melting reactions and source-rock fertility, in Evolution and Differentiation of the Continental Crust, edited by M. Brown, and T. Rushmer, pp. 296-325, Cambridge University Press.

Clowes, R. M., A. J. Calvert, D. W. Eaton, Z. Hajnal, J. Hall, and G. M. Ross (1996), LITHOPROBE reflection studies of Archean and Proterozoic crust in Canada, Tectonophysics, 264, 65-88.

Cook, F. A. (2002), Fine structure of the continental reflection Moho, Geol. Soc. Am. Bull., 114, 64-79.

Cook, F. A., L. D. Brown, S. Kaufman, J. E. Oliver, and T. A. Petersen (1981), COCORP seismic profiling of the Appalachian Orogen beneath the coastal plain of Georgia, Geol. Soc. Am. Bull., 92, 738-748.

Cook, F. A., A. J. van der Velden, K. W. Hall, and B. J. Roberts (1999), Frozen subduction in Canada's Northwest territories: Lithoprobe deep lithospheric reflection profiling of the western Canadian Shield, Tectonics, 18, 1-24.

Crespo-Blanc, A. (1992), Structure and kinematics of a sinistral transpressive suture between the Ossa-Morena and the South Portuguese Zones, South Iberian Massif, J. Geol. Soc. London, 149, 401-411.

Crespo-Blanc, A., and M. Orozco (1988), The Southern Iberian Shear Zone: A major boundary in the Hercynian folded belt, Tectonophysics, 148, 221-227.

DEKORP Research Group (1985), First results and preliminary interpretations of deep reflection seismic recording along profile DEKORP 2-South, J. Geophys., 57, 137-163.

DEKORP Research Group (1990), Crustal structure of the Rhenish Massif: Results of deep seismic reflection lines DEKORP 2-N and 2-N-Q, Geol. Rundsch., 79, 523-566.

DEKORP Research Group (1991), Results of the DEKORP 1 (BELCORPDEKORP) deep seismic reflection studies in the western part of the Rhenish Massif, Geophys. J. Int., 106, 203-227.

Díez Balda, A., J. R. Martínez Catalán, and P. Ayarza (1995), Syn-collisional extensional collapse parallel to the orogenic trend in a domain of steep tectonics: The Salamanca detachment zone (Central Iberian Zone, Spain). J. Struct. Geol., 17, 163-182.

Echtler, H. P., M. Stiller, F. Steinhoff, C. Krawczyk, A. Suleimanov, V. Spiridonov, J. H. Knapp, Y. Menshikov, J. Alvarez Marrón, and N. Yunusov (1996), Preserved collisional crustal structure of the southern Urals revealed by vibroseis profiling, Science, 274(5285), 224-226.

England, P. C., and A. Thompson (1986), Some thermal and tectonic models for crustal melting in continental collision zones, in Collision Tectonics, edited by M. P. Coward, and A. C. Ries, pp. 83-94, Geol. Soc. London, Special Publication 19, Blackwell Sci. Publ., Oxford.

Escuder Viruete, J., R. Arenas, and J. R. Martínez Catalán (1994), Tectonothermal evolution associated with Variscan crustal extension in the Dormes Gneis Dome (NW Salamanca, Iberian Massif, Spain), Tectonophysics, 238, 117-138. 


\section{SIMANCAS ET AL.: SEISMIC GEOTRAVERSE IBERIAN VARISCIDES}

Escuder Viruete, J., P. P. Hernáiz, P. Valverde Vaquero, R. Rodríguez Fernández, and G. Dunning (1998), Variscan syncollisional extension in the Iberian Massif: Structural, metamorphic and geochronological evidence from the Somosierra sector of the Sierra de Guadarrama (Central Iberian Zone, Spain), Tectonophysics, 290, 87-109.

Fernández Suárez, J., G. R. Dunning, G. A. Jenner, and G. Gutiérrez-Alonso (2000), Variscan collisional magmatism and deformation in NW Iberia Constraints from U-Pb geochronology of granitoids, J. Geol. Soc. London, 157, 565-576.

Flecha, I., I. Palomeras, R. Carbonell, J. F. Simancas, P. Ayarza, J. Matas, F. González Lodeiro, and A. Pérez Estaún (2009), Seismic imaging and modelling of the lithosphere of SW-Iberia, Tectonophysics, 472, 148-157, doi:10.1016/j.tecto.2008.05.033.

Fonseca, P., and A. Ribeiro (1993), Tectonics of the Beja-Acebuches Ophiolite: A major suture in the Iberian Variscan Fold-belt, Geol. Rundsch., 82, 440-447.

Fonseca, P., J. Munhá, J. Pedro, F. Rosas, P. Moita, A. Araujo, and N. Leal (1999), Variscan ophiolites and high-pressure metamorphism in Southern Iberia, Ofioliti, 24, 259-268.

Franke, W. (2000), The mid-European segment of the Variscides: Tectonostratigraphic units, terrane boundaries and plate tectonic evolution, in Orogenic Processes: Quantification and Modelling in the Variscan Belt, edited by W. Franke, V. Haak, O. Oncken, and D. Tanner, pp. 35-61, Geol. Soc. London, Special Publication 179, Geol. Soc., London.

Gómez Pugnaire, M. T., A. Azor, V. López Sánchez Vizcaino, and M. Soler (2003), The amphibolites from the Ossa-Morena/Central Iberian Variscan suture (southwestern Iberian Massif): Geochemistry and tectonic interpretation, Lithos, 68, 23-42.

Gutiérrez-Alonso, G., J. Fernández-Suárez, and A. B. Weil (2004), Orocline triggered lithospheric delamination, Geol. Soc. Am. Special Paper, 383 , $121-130$.

Hammer, P. T. C., R. M. Clowes, F. A. Cook, K. Vasudevan, and A. J. van der Velden (2011), The big picture: A lithospheric cross section of the North American continent, GSA Today, 21(6), doi:10.1130/ GSATG95A.1.

Harry, D. L., J. S. Oldow, and D. S. Sawyer (1995), The growth of orogenic belts and the role of crustal heterogeneities in decollement tectonics, Geol. Soc. Am. Bull., 107, 1411-1426.

Hernández Enrile, J. L. (1991), Extensional tectonics of the Toledo ductilebrittle shear zone, Central Iberian Massif, Tectonophysics, 191, 311-324.

Jackson, P., and D. J. Sanderson (1992), Scaling of faults displacements from the Badajoz-Córdoba shear zone SW Spain, Tectonophysics, 210 179-190.

Juhlin, C., M. Friberg, H. P. Echtler, T. Hismatulin, A. Rybalka, A. G. Green, and J. Ansorge (1998), Crustal structure of the Middle Urals: Results from the (ESRU) Europrobe seismic reflection profiling in the Urals experiments, Tectonics, 17, 710-725.

Kashubin, A. S., and C. Juhlin (2010), Mapping of crustal scale tectonic Boundaries in the Ossa-Morena Zone using reprocessed IBERSEIS reflection seismic data, Tectonophysics, 489, 139-158.

López Sánchez-Vizcaíno, V., M. T. Gómez-Pugnaire, A. Azor, and J. M. Fernández Soler (2003), Phase diagram sections applied to amphibolites: A case study from the Ossa-Morena/Central Iberian Variscan suture (Southwestern Iberian Massif), Lithos, 68, 1-21.

Macaya, J., F. González Lodeiro, J. R. Martínez Catalán, and F. Álvarez (1991), Continuous deformation ductile thrusting and backfolding of cover and basement in the Sierra de Guadarrama Hercynian orogen of central Spain, Tectonophysics, 191, 291-309.

Marcos, A. (2004), Zona Asturoccidental-Leonesa, in Geología de España, edited by J. A. Vera, pp. 49-68, SGE-IGME, Madrid.

Martínez Catalán, J. R. (2011), Are the oroclines of the Variscan belt related to late Variscan strike-slip tectonics? Terra Nova, 23, 241-247.

Martínez Catalán, J. R. (2012), The Central Iberian arc, an orocline centered in the Iberian Massif and some implications for the Variscan belt, Int. J. Earth Sci. (Geol Rundsch), 101, 1299-1314, doi:10.1007/s005311-0715-6.

Martínez Catalán, J. R., et al. (1995), Results from the ESCI-N3.3 marine deep seismic profile along the Cantabrian continental margin, Rev. Soc. Geológica de España, 8, 341-354.

Martínez Catalán, J. R., R. Arenas, F. Díaz García, F. J. Rubio Pascual, J. Abati, and J. Marquínez (1996), Variscan exhumation of a subducted Paleozoic continental margin: The basal units of the Ordenes Complex, Galicia, NW Spain, Tectonics, 15, 106-121.

Martínez Catalán, J. R., D. Martínez Poyatos, and F. Bea (2004) Zona Centroibérica, in Geología de España, edited by J. A. Vera, pp. 68-133, SGE-IGME, Madrid.

Martínez Poyatos, D., et al. (2012), Imaging the crustal structure of the Central Iberian Zone (Variscan Belt): The ALCUDIA deep seismic reflection transect, Tectonics, 31, TC3017, doi:10.1029/2011TC002995.
Matte, P. (1986), Tectonics and plate tectonics model for the Variscan Belt of Europe, Tectonophysics, 126, 329-374.

Matte, P. (2001), The Variscan collage and orogeny (480-290 Ma) and the tectonic definition of the Armorica microplate: A review, Terra Nova, 13, $122-128$.

Matte, P., and A. Ribeiro (1975), Forme et orientation de l'ellipsoïde de déformation dans la virgation hercynienne de Galice. Relations avec le plissement et hypthèses sur la génèse de l'arc ibéro-armoricain, $C . R$. Acad. Sci. Paris, 280, 2825-2828.

Meissner, R. (1999), Terrane accumulation and collapse in central Europe: Seismic and rheological constraints, Tectonophysics, 305, 93-107.

Montero, P., F. Bea, T. F. Zinger, J. H. Scarrow, J. F. Molina, and M. Whitehouse (2004), 55 million years of continuous anatexis in Central Iberia: Single-zircon dating of the Peña Negra Complex, J. Geol. Soc. London, 161, 255-263.

Oldow, J. S., Bally, A. W., and Avé Lallemant, H. (1990), Transpression, orogenic float and lithospheric balance, Geology, 18, 991-994.

Oliveira, J. T. (1990), The South Portuguese Zone: Stratigraphy and synsedimentary tectonism, in Pre-Mesozoic Geology of Iberia, edited by R. D. Dallmeyer, and E. Martínez, pp. 334-347, Springer-Verlag, Berlin. Ordóñez Casado, B. (1998), Geochronological studies of the Pre-Mesozoic basement of the Iberian Massif. The Ossa-Morena zone and the Allochthonous Complexes within the Central Iberian zone. M.S.thesis, Univ. of Zurich, Switzerland.

Orejana, D., C. Villaseca, R. A. Armstrong, and T. E. Jeffries (2011), Geochronology and trace element chemistry of zircon and garnet from granulite xenoliths: Constraints on the tectonothermal evolution of the lower crust under Central Spain, Lithos, 124, 103-116.

Orejana, D., C. Villaseca, P. Valverde-Vaquero, E. A. Belousova, and R. A. Armstrong (2012), U-Pb geochronology and zircon composition of late Variscan S- and I-type granitoids from the Spanish Central System batholith, Int. J. Earth Sci. (Geol Rundsch), 101, 1789-1815.

Oschner, A. (1993), U-Pb geochronology of the Upper Proterozoic lower Paleozoic geodynamic evolution in the Ossa-Morena Zone (SW Iberia) Constraints on the time of the Cadomioan Orogeny. M.S. thesis, Univ. of Zurich, Switzerland.

Palomeras, I., R. Carbonell, I. Flecha, J. F. Simancas, P. Ayarza, J. Matas, D. Martínez Poyatos, A. Azor, F. González Lodeiro, and A. Pérez Estaún (2009), Nature of the lithosphere across the Variscan orogen of SW Iberia JGR: Dense wide-angle seismic reflection data, J. Geophys. Res., 114, B02302, doi:10.1029/2007JB005050.

Palomeras, I., R. Carbonell, P. Ayarza, M. Fernández, J. F. Simancas, D. Martínez Poyatos, F. González Lodeiro, and A. Pérez Estaún (2011), Geophysical model of the lithosphere across the Variscan Belt of SW Iberia: Multidisciplinary assessment, Tectonophysics, 508, 42-51, doi:10.1016/j.tecto.2010.07.010.

Pedro, J., A. Araújo, P. Fonseca, C. Tassinari, and A. Ribeiro (2010), Geochemistry and U-Pb zircon age of the internal Ossa-Morena zone ophiolite sequences: A remnant of Rheic Ocean in SW Iberia, Ofioliti, 35, 117-130.

Pereira, M. F., A. Apraiz, J. B. Silva, and M. Chichorro (2008) Tectonophermal analysis of high-temperature mylonitization in the Coimbra-Córdoba shear zone (SW Iberian Massif, Ouguela tectonic unit, Portugal): Evidence of intracontinental transcurrent transport during the amalgamation of Pangea, Tectonophysics, 461, 378-394.

Pérez Estaún, A., F. Bastida, J. L. Alonso, J. Marquínez, J. Aller, J. ÁlvarezMarrón, A. Marcos, and J. A. Pulgar (1988), A thin-skinned tectonic model for an arcuate fold and thrust belt: The Cantabrian Zone (Variscan Ibero-Armorican Arc), Tectonics, 7, 517-537.

Pérez Estaún, A., J. R. Martínez Catalán, and F. Bastida (1991), Crustal thickening and deformation sequence in the footwall to the suture of the Variscan belt of northwest Spain, Tectonophysics, 191, 243-253.

Pérez Estaún, A., J. A. Pulgar, E. Banda, J. Alvarez-Marrón, and ESCI-N Research Group (1994), Crustal structure of the external variscides in northwest Spain from deep seismic reflection profiling, Tectonophysics, 232, 91-118.

Pfiffner, O. A., S. Ellis, and C. Beaumont (2000), Collision tectonics in the Swiss Alps: Insight from geodynamic modelling, Tectonics, 19, 1065-1094.

Pin, C., P. Fonseca, J. L. Paquette, P. Castro, and P. Matte (2008), The ca. $350 \mathrm{Ma}$ Beja Igneous Complex: A record of transcurrent slab break-off in the southern Iberia Variscan belt?, Tectonophysics, 461, 356-377, doi:10.1016/j.tecto.2008.06.001.

Ponce, C., J. F. Simancas, A. Azor, D. Martínez Poyatos, G. Booth-Rea, and I. Expósito (2012), Metamorphism and kinematics of the early deformation in the Variscan suture of SW Iberia, J. Metamorph. Geol., 30 , 625-638, doi:10.1111/j.1525-1314.2012.00988.x.

Pulgar, J. A., A. Pérez Estaún, J. Gallart, J. Álvarez Marrón, J. Gallastegui, J. L. Alonso, and ESCIN Group (1995), The ESCI-N2 deep seismic reflection profile: A traverse across the Cantabrian Mountains and adjacent Duero basin, Rev. Soc. Geológica de España, 8, 383-394. 


\section{SIMANCAS ET AL.: SEISMIC GEOTRAVERSE IBERIAN VARISCIDES}

Quinlan, G., C. Beaumont, and J. Hall (1993), Tectonic model for crustal seismic reflectivity patterns in compressional orogens, Geology, 21, 663-666.

Ranalli, G., and D. C. Murphy (1987), Rheological stratification of the lithosphere, Tectonophysics, 132, 281-296.

Ribeiro, A., et al. (2007), Geodynamic evolution of the SW Europe Variscides, Tectonics, 26, TC6009, doi:10.1029/2006TC002058.

Royden, L. (1996), Coupling and decoupling of crust and mantle in convergent orogens: Implications for strain partitioning in the crust, J. Geophys. Res., 101(B8), 17,679-17,705.

Rubio Pascual, F. J., R. Arenas, J. R. Martínez Catalán, L. R. Rodríguez Fernández, and J. R. Wijbrans (2013), Thickening and exhumation of the Variscan roots of the Iberian Central System: Tectonothermal processes and ${ }^{40} \mathrm{Ar} /{ }^{39} \mathrm{Ar}$ ages, Tectonophysics, 587, 207-221.

Schäfer, H. J. (1991), Geochronological investigations in the Ossa-Morena Zone, SW Spain. M.S. thesis, Univ. of Zurich, Switzerland.

Schermerhörn, L. J. G. (1975), Spilites, regional metamorphism and subduction in the Iberian Pyrite Belt: Some comments, Geol. Mijnbouw, 54, 23-35.

Schmelzbach, C., J. F. Simancas, C. Juhlin, and R. Carbonell (2008), Seismic reflection imaging over the South Portuguese Zone foldand-thrust belt, SW Iberia, J. Geophys. Res., 113, B08301, doi:10.1029/ 2007JB005341.

Seyferth, M., and A. Henk (2004), Syn-convergent exhumation and lateral extrusion in continental collision zones-insights from threedimensional numerical modelling, Tectonophysics, 382, 1-29.

Shaw, J., S. T. Johnston, G. Gutiérrez-Alonso, and A. B. Weil (2012), Oroclines of the Variscan orogen of Iberia: Paleocurrent analysis and paleogeographic implications, Earth Planet. Sci. Lett., 329-330, 60-70.

Simancas, J. F., D. Martínez Poyatos, I. Expósito, A. Azor, and F. González Lodeiro (2001), The structure of a major suture zone in the SW Iberian Massif: The Ossa-Morena/Central Iberian contact, Tectonophysics, 332, 295-308.

Simancas, J. F., et al. (2003), The crustal structure of the transpressional Variscan Orogen of SW Iberia: The IBERSEIS deep seismic reflection profile, Tectonics, 22(6), 1062, doi:10.1029/2002TC001479.

Simancas, J. F., A. Tahiri, A. Azor, F. González Lodeiro, D. Martínez Poyatos, and H. El Hadi (2005), The tectonic frame of the VariscanAlleghanian Orogen in Southern Europe and Northern Africa, Tectonophysics, 398, 181-198.

Simancas, J. F., et al. (2006), Transpressional collision tectonics and mantle plume dynamics: The variscides of southwestern Iberia, in European
Lithosphere Dynamics, edited by G. D. Gee, R. A. Stephenson, pp. 345-354, Geol. Soc. London, Memoirs 32, Geol. Soc., London.

Soriano, C., and J. M. Casas (2002), Cross section through the central part of the Iberian Pyrite Belt, South Portuguese zone (Spain), in Variscan-Appalachian Dynamics: The Building of the Late Paleozoic Basement, edited by J. R. Martínez Catalán, et al., pp. 183-197, Geol. Soc. Am. Special Paper 364, Geol. Soc. of Am., Boulder, Colo.

Tryggvason, A., D. Brown, and A. Pérez-Estaún (2001), Crustal architecture of the southern Uralides from true amplitude processing of the Urals Seismic Experiment and Integrated Studies (URSEIS) vibroseis profile, Tectonics, 20, 1040-1052.

Valenzuela, A., T. Donaire, C. Pin, M. Toscano, M. A. Hamilton, and E. Pascual (2011), Geochemistry and U-Pb dating of felsic volcanic rocks in the Riotinto-Nerva unit, Iberian Pyrite Belt, Spain: Crustal thinning, progressive crustal melting and massive sulphide genesis, J. Geol. Soc. London, 168, 717-731, doi:10.1144/0016-764920-10-081.

Valle Aguado, B., M. R. Azevedo, U. Schalteger, J. R. Martínez Catalán, and J. Nolan (2005), U-Pb zircon and monazite geochronology of Variscan magmatism related to syn-convergence extension in Central Northern Portugal, Lithos, 82, 169-184.

Valverde-Vaquero, P., G. R. Dunning, P. Hernáiz-Huerta, and J. EscuderViruete (1995), Early-mid Carboniferous Variscan syn-collisional extension in the Central Iberian Zone (Iberian Massif, Central Spain): Time constraints from the Somosierra area of the Sierra de Guadarrama, paper presented at $26^{\text {th }}$ Annual Meeting of the Tectonic Studies group, Cardiff, United Kingdom.

Villaseca, C., L. Barbero, and G. Rogers (1998), Crustal origin of Hercynian peraluminious granitic batholiths of Central Spain: Petrological, geochemical and isotopic ( $\mathrm{Sr}, \mathrm{Nd})$ arguments, Lithos, 43, 55-79.

Villaseca, C., H. Downes, C. Pin, and L. Barbero (1999), Nature and composition of the lower continental crust in central Spain and the granulite-granite linkage: Inferences from granulitic xenoliths, J. Petrol., 40, 1465-1496.

Villaseca, C., D. Orejana, and E. A. Belousova (2012), Recycled metaigneous crustal sources for S- and I-type Variscan granitoids from the Spanish Central System batholith: Constraints from Hf isotope zircon composition, Lithos, 153, 84-93.

Weil, A. B., R. Van der Voo, B. A. van der Plujim, and J. M. Parés (2000), The formation of an orocline by multiphase deformation: A paleomagnetic investigation of the Cantabria-Asturias Arc (northern Spain). J. Struct. Geol., 22, 735-756. 